Bruno Albert Navarro

Osteologia pós-craniana e relações filogenéticas do titanossauro do Cretáceo Inferior Tapuiasaurus macedoi Zaher et al. 2011

Postcranial osteology and phylogenetic relationships of the Early Cretaceous titanosaur Tapuiasaurus macedoi

Zaher et al. 2011

Volume 1 - Main text

São Paulo

2019 
Osteologia pós-craniana e relações filogenéticas do titanossauro do Cretáceo Inferior Tapuiasaurus macedoi Zaher et al. 2011

Postcranial osteology and phylogenetic relationships of the Early Cretaceous titanosaur Tapuiasaurus macedoi Zaher et al. 2011

Dissertation presented to the Departamento de Zoologia do Instituto de Biociências da Universidade de São Paulo, as part of the requirements for obtaining the Master of Science Degree with emphasis in Zoology.

Advisor: Prof. Dr. Hussam El Dine Zaher

São Paulo 


\section{Cataloging Sheet}

Navarro, Bruno A.

Osteologia pós-craniana e relações filogenéticas do titanossauro do Cretáceo

Inferior Tapuiasaurus macedoi Zaher et al. 2011 : Postcranial osteology and phylogenetic relationships of the Early Cretaceous titanosaur Tapuiasaurus macedoi Zaher et al. 2011 / Bruno Albert Navarro; orientador Hussam El Dine Zaher. - São Paulo, 2019.

\section{3 f. + anexos}

Dissertação (Mestrado) - Instituto de Biociências da Universidade de São Paulo, Departamento de Zoologia.

1. Cretáceo Inferior 2. Titanosauria 3. Tapuiasaurus macedoi 4. Osteologia 5. Filogenia I. Zaher, Hussam El Dine, orient. II. Título.

Judging Committee

Prof. Dr.

Prof. Dr.

Prof. Dr. Hussam El Dine Zaher

MZUSP / IBUSP

Advisor 


\section{Dedicatory}

To my family and many friends who have always believed in my potential and encouraged me. 


\section{Epigraph}

"Quem elegeu a busca não pode recusar a travessia".

"Who elected the search, cannot refuse the crossing" 


\section{Acknowledgements}

This study was financed by the Coordenação de Aperfeiçoamento de Pessoal de Nível Superior - Brasil (CAPES) - Finance Code 001, and by the Conselho Nacional de Desenvolvimento Científico e Tecnológico - Brasil (CNPq), grant \# 130.280/2018-6, in which, without this foment, its realization would not be possible.

Firstly, I am deeply grateful to Hussam Zaher, due not only for having agreed to advise me but also for him being a great friend. Your help and encouragement I will carry for the rest of my life. Thank you HZ for all the opportunities, for trust in my work and for broadening my horizons.

I would also like to thank Jeffrey Wilson (University of Michigan) for gift me with his vast experience in the sauropod anatomy. It was a great pleasure to work together. Thanks a lot JAW, for the valuable lessons. I hope that we can extend this partnership, which I am sure will yield great results.

I could not fail to thank you immensely Alberto Barbosa de Carvalho, for all support, friendship and companionship since I joined in the MZ-USP. My career would be nothing if it were not for your teachings and your values.

I also could not forget to thank for all the good moments of friendship and experience exchange with my colleagues Aline Staskowian, Ana Botallo, André Cattaruzzi, Bruno Augusta, Bruno Rocha, Daniela Gennari, Ernesto Aranda, Fausto Erritto, Felipe Grazziotin, Flávio Molina, Gabriela Sobral, Juan Camilo, Leonardo de Oliveira, Lucas Siffert, Luís Bio, Natalia Rizzo, Paola Sánchez, Paulo Machado, Roberta Graboski, Rodolfo Santos, Rosely Rodrigues, Scott Thomson, Vanessa Yamamoto, Vivian Trevine and Wellton Araújo from the Laboratories of Paleontology and Herpetology of MZ-USP, always willing to help me. I especially want to thank to Lucas Piazentin (the little grasshopper), Eduardo Gouveia (Duzão) and Daniella França for all support in the conclusion of this study.

During the data collection phase of this research, I had the honor of knowing awesome specimens, and this was only possible through the help of such wonderful people. Here I offer my most sincere thanks:

- To my friends Natan Brilhante (MN-UFRJ) and Barbara Maciel (MN-UFRJ) who so kindly welcomed me into your house during my visit to the Rio de Janeiro collections; 
- To Dr. Luciana Barbosa de Carvalho and Dr. Sérgio Alex K. Azevedo for allow the study of the specimens deposited at the Museu Nacional (MN-UFRJ);

- To Dr. Rodrigo Machado for allow the study of the specimens deposited at the Museu de Ciências da Terra (MCT-DNPM-CPRM), and Msc. Leonardo Carneiro (UFPE) by the company and help during the stay in this collection;

- To Dr. Sandra Tavares and all staff for allow the study of the specimens deposited at the Museu de Paleontologia de Monte Alto (MPMA);

- To Dr. Fabiano Iori and Leonardo Pachoa for allow the study of the specimens deposited at the Museu de Paleontologia Pedro Candolo (MPPC);

- To Dr. Thiago Marinho, Msc. Julian C. G. Silva Junior, Dr. Luiz Carlos Borges Ribeiro, Álvaro Marcelo Carneiro Monteiro Guedes and all staff for allow the study of the specimens deposited at the Complexo Cultural e Científico de Peirópolis (CCCP-UFTM);

- To Dr. Douglas Riff, Msc. Rafael Souza and Vinícius Campos for allow the study of the specimens deposited at the Museu de Biociências (MBC-UFU);

- To Dr. Fernando Pires and all staff for allow the study of the specimens deposited at the Museu Geológico Valdemar Lefèvre (MUGEO).

I also want to thank many colleagues who have helped me a lot with discussions about this work, such as Dr. Rafael Delcourt (UNICAMP), Dr. Diego Pol (MEF), Dr. Pedro Mocho (NHMLAC), Dr. Marcelo Fernandes, Dr. Aline Ghilardi, MSc. Tito Aureliano, MSc. Bernardo Peixoto and MSc. Pedro Buck (LPP-UFSCar).

I am deeply grateful to Sérgio Lages (UFMG) for your help and wonderful talent employed with the Tapuiasaurus illustrations.

I reserve a special thanks to Kamila Bandeira (MN-UFRJ). Friend, work and travel partner, helped me in different ways at critical times of the work, is when I lost data or when needed opinions. Thanks a lot Kalu (also known as Miss Titanosauria) for your friendship!

Last but not least, I thank to my Mom (Genara O. Albert), to my brother (Matheus Albert) and my sister (Nathalia Albert) for all support, direct and indirect, not only in this work but in many moments of my life. 
Summary

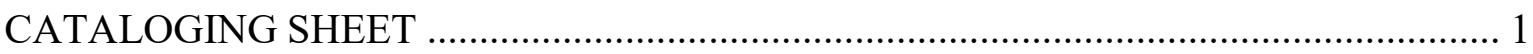

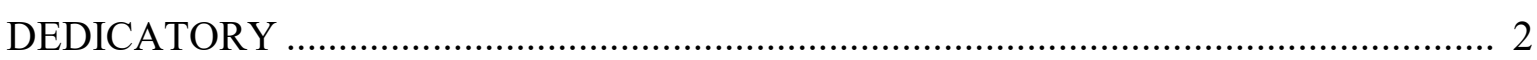

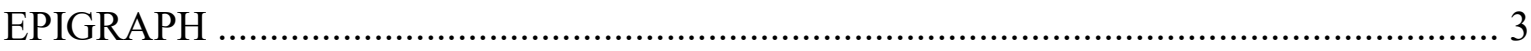

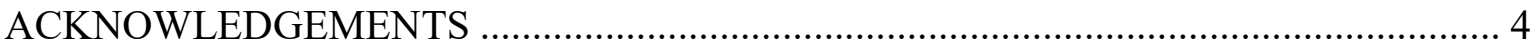

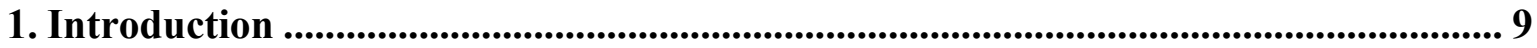

1.1. A brief review of titanosaurian anatomy, systematics and taxonomy .................... 12

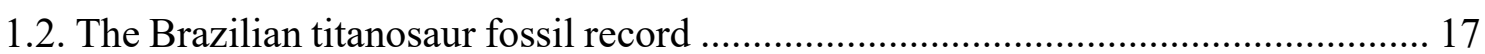

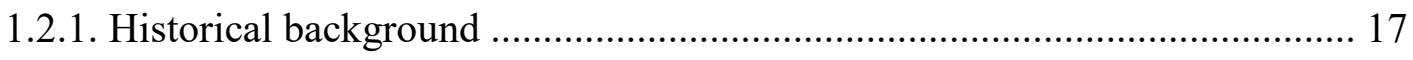

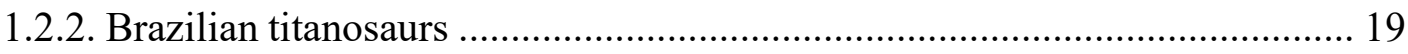

1.2.1.1 Systematic Paleontology ............................................................ 19

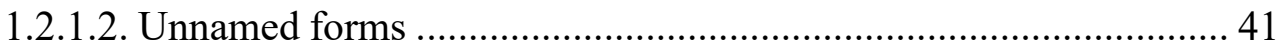

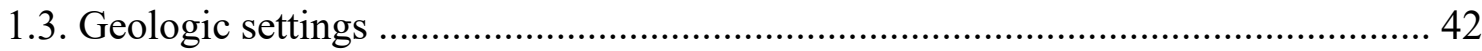

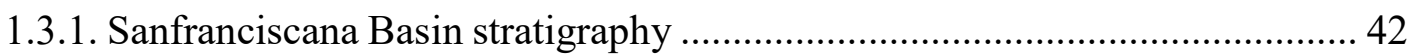

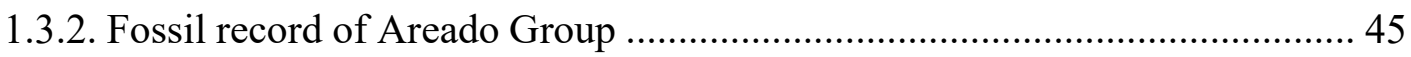

1.3.3. Revaluation of the Quiricó Formation age ................................................ 47

1.3.4. The Tapuiasaurus macedoi type locality ...................................................... 49

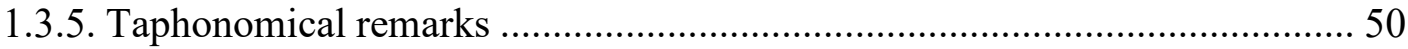

2. Objectives .............................................................................................................................................. 51

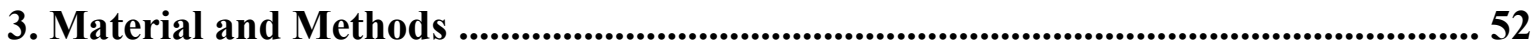

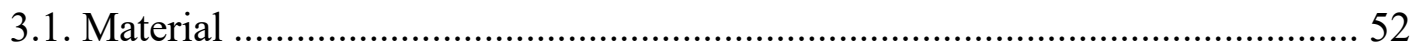

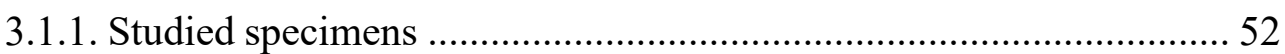

3.1.2. Specimens employed in comparisons ......................................... 52

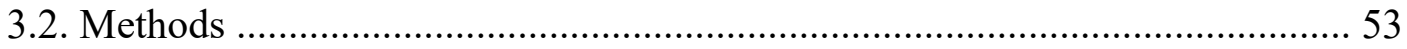

3.2.1. Osteological and directional terminology ..................................... 53

3.2.2. Preparation and study of the specimens ......................................... 53

3.2.3. Phylogenetic inference .................................................................. 54

3.2.3.1. Data matrix construction ................................................. 54

3.2.3.2. Operational Taxonomic Units scoring .............................. 54

3.2.3.3. Heuristic tree search protocol ............................................ 54

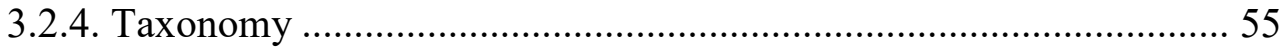


4. Results .............................................................................................................................. 56

4.1. Systematic Paleontology …………………………………………………. 56

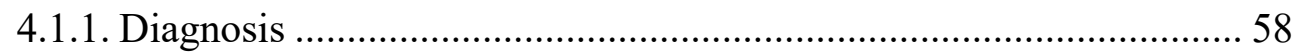

4.1.1.1. Original diagnosis provided by Zaher et al. 2011 .............. 58

4.1.1.2. Emended diagnosis provided by Wilson et al. 2016 .......... 58

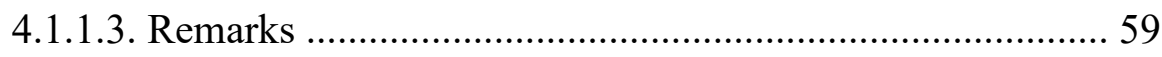

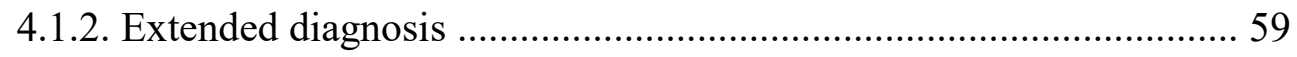

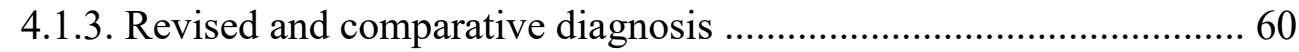

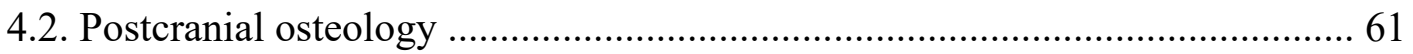

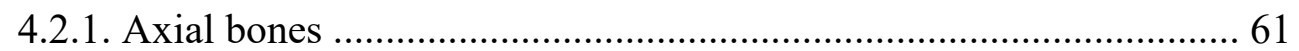

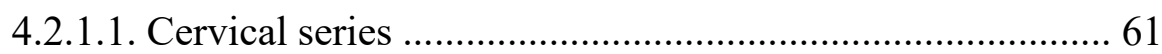

4.2.1.1.1. Proatlas and Atlas-Axis complex ......................... 61

4.2.1.1.2. Anterior cervical ...................................................... 64

4.2.1.1.3. Middle cervical .................................................. 65

4.2.1.1.4. Posterior cervical .................................................. 66

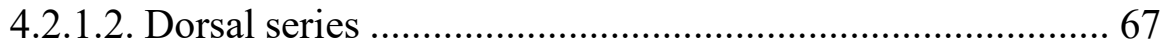

4.2.1.1.1. Middle dorsal ........................................................ 67

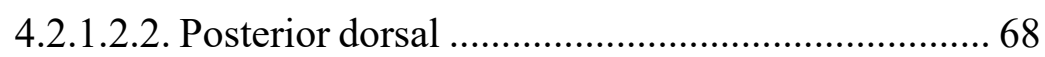

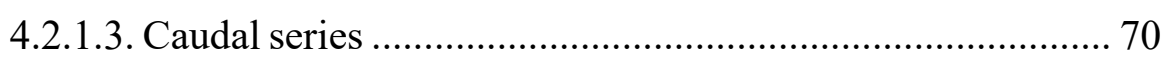

4.2.1.3.1. Chevrons .............................................................. 71

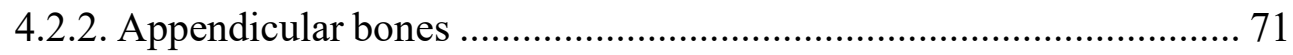

4.2.2.1. Pectoral girdle ………………………………………......... 71

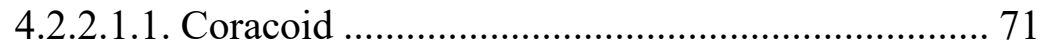

4.2.2.1.2. Sternal plate ………………………………….... 72

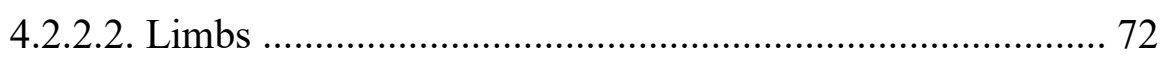

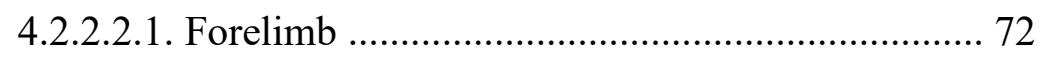

4.2.2.2.1.1. Humerus ............................................... 72

4.2.2.2.1.2. Ulnae ................................................... 73

4.2.2.2.1.3. Radius .................................................. 73

4.2.2.2.1.4. Manus .................................................. 74

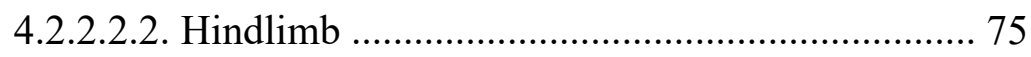

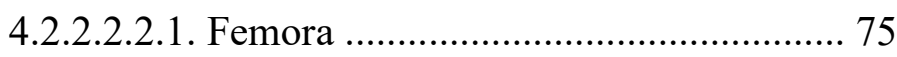

4.2.2.2.2.2. Fibula ……………………………........ 76

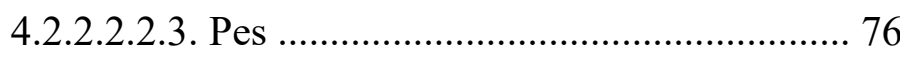


4.3. Phylogenetic analysis 80

5. Discussion

5.1. Comparative osteology and diagnostic features of Tapuiasaurus 83

5.2. Phylogenetic relationships of Tapuiasaurus and biogeographic

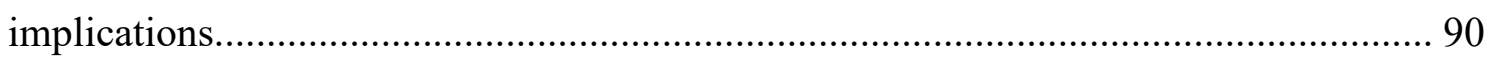

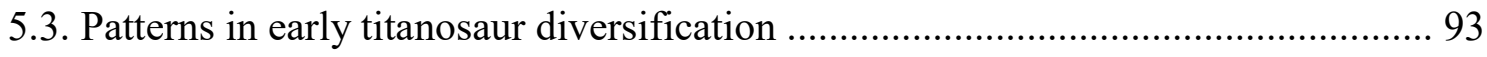

6. Conclusions ........................................................................................................................................... 97

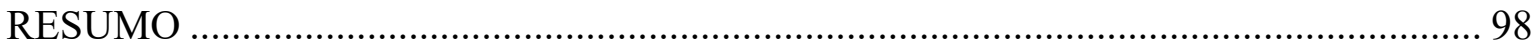

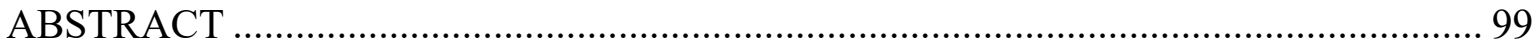

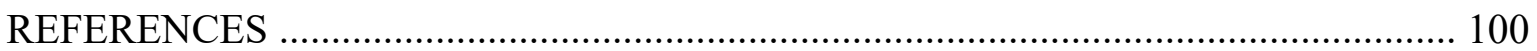




\section{1 - Introduction}

More than a decade ago, the Paleontology Laboratory from the Museu de Zoologia da Universidade de São Paulo (MZUSP) opened a new frontier in dinosaur research in Brazil. The MZUSP team started several field seasons in the deposits of Sanfranciscana Basin, located at the outskirts of Coração de Jesus Municipality, north of the Minas Gerais State, South-eastern Brazil (Pires Domingues 2009). The fieldwork was carried in outcrops of the Early Cretaceous Quiricó Formation, which yielded remarkable specimens unexpected for this geological unit at this point, such as the remains of sauropod (Titanosauria) and theropod (Abelisauroidea) dinosaurs (Pires Domingues 2009, Zaher et al. 2011, Da Silva 2013).

Among the collected individuals, there is one the most complete titanosaur specimens recovered from Brazil so far: Tapuiasaurus macedoi Zaher et al. 2011. This finding stands out because, among the recovered materials, the skull and jaws are complete, articulated and exceptionally preserved, a rare fact in the fossil record of this group, representing one of the most complete skulls recovered in the world and the first for a Brazilian titanosaur (Zaher et al. 2011, Bittencourt et al. 2015, Wilson et al. 2016).

Over a sesquicentennial history of titanosaur research, just other four species with almost complete skulls have been described until now. They consist in the partial skulls of Nemegtosaurus mongoliensis and Quaesitosaurus orientalis from the latest Cretaceous (Maastrichtian and Campanian respectively) Nemegt and Bayun Goyot formations, Mongolia (Nowinski 1971, Kurzanov \& Bannikov 1983, Wilson 2005); the disarticulated skulls of Rapetosaurus krausei from the Maastrichtian Maevarano Formation of Madagascar (Curry Rogers \& Forster 2001, 2004); and the complete skull of Sarmientosaurus musacchioi (Martínez et al. 2016) from the early Late Cretaceous (Cenomanian-Turonian) Bajo Barreal Formation of Argentina. Hence, Tapuiasaurus constitutes the first and only complete titanosaur skull from the Early Cretaceous time-interval known up to date (Wilson et al. 2016).

Beyond the skull remains, the holotype of Tapuiasaurus (MZSP-PV 807) preserves anatomical regions of great significance for the knowledge of general titanosaurian anatomy, such as an articulated part of it cervical sequence, dorsal and caudal vertebrae, as well as almost complete fore and hindlimbs, including one nearly complete left foot, which is 
another region poorly sampled for Sauropoda as whole. Although recent works have been focused on this part of the appendicular skeleton (e.g. González Riga et al. 2008, 2016), due to limited sampling, the evolution of sauropod pedal anatomy remains poorly understood, allowing Tapuiasaurus to become a good model for character polarization.

The importance of this taxon to the knowledge of titanosaurian morphological evolution does not lie only in the preservation of poorly sampled anatomical regions, but also because Tapuiasaurus is one of the oldest representatives of this group, filling a crucial gap (i.e. Berriasian to Barremian) in the early stages of the titanosaurian dispersion around the world (Carballido et al. 2017, Poropat et al. 2017, Sallam et al. 2018). Tapuiasaurus, being also one of the first "true" titanosaurians, which broadens the understanding about initial steps in the titanosaur evolution, even if the ichnological record supports an earlier titanosaur cladogenesis, placing the group origins into the Middle Jurassic (Wilson \& Carrano 1999, Curry Rogers 2005).

The enigmatic African taxa Janenschia robusta and Tendaguria tanzaniensis (Wild 1991, Bonaparte et al. 2000), from the Late Jurassic Tendaguru Beds of Tanzania, may correspond to putative Jurassic titanosaurians (McIntosh 1990, Curry Rogers 2005), despite these taxa being likely related to non-titanosauriform sauropodans according some authors (Santucci 2005, Upchurch et al. 2015, Mannion et al. 2019). Even if these species correspond to true early titanosaurians or immediate sister-groups, a significant temporal and morphological gap exists between the limited Jurassic forms and the diverse and widespread titanosaurs from the Late Cretaceous, creating a ghost-lineage of, at least, $50 \mathrm{My}$. Tapuiasaurus is there at the midst of this unclear period of titanosaur evolution, given that available occurrences from this age are limited to punctuated and highly fragmentary specimens.

Contrasting with the abundance of later forms, titanosaurians from the earliest Cretaceous are scarcer and represented mostly by very fragmentary or dubious taxa. From South America, the oldest titanosaurian record for a long time comprised by an isolated procoelous caudal vertebra of an undetermined form recovered from the Aptian Rayoso Formation (Neuquén Basin), Argentina (Bonaparte 1996). Recently, Ghilardi et al. (2016) and Carvalho et al. (2017) described older titanosaurian remains, recovered from the Hauterivian-Barremian Rio Piranhas Formation (Rio do Peixe Basin Complex), Northeastern of Brazil. They consist of the isolated fibula of an unnamed form and by the 
putative early titanosaur Triunfosaurus leonardii (composed by an ischium, chevrons and three partial mid caudal vertebrae). However, some authors suggests that Triunfosaurus represents a non-titanosaurian somphospodylian, such as Wintonotitan wattsi (Poropat et al. 2014, 2017).

Outside South America, titanosaurs prior to Aptian time-interval are represented by an undetermined form composed by two large procoelous mid-caudal vertebrae, and by the nomen dubium taxon Iuticosaurus valdensis, both recovered from the Barremian-Aptian Wessex Formation (Wealden Group) of England (Le Loeuff 1993, Upchurch et al. 2011). The coeval taxa Eucamerotus foxi and Haestasaurus becklesii, composed by several nonassociated dorsal neural arch and vertebrae and a nearly complete forelimb respectively, may correspond to another putative titanosaurians from the earliest Cretaceous (BerriasianValanginian, Santucci 2005), although it being likely related to brachiosaurids rather than titanosaurians (Blows 1995, Upchurch et al. 2011, 2015).

From the Murtoi Formation, Transbaikalia, Russia, Averianov and Skutschas (2017) describes three procoelous mid caudal vertebrae, which assigned to a new species, Tengrisaurus starkovi, representing the first unequivocal Early Cretaceous lithostrotian from Asia. More recently, Averianov and Efimov (2018) described, from marine deposits located nearly the Volga River, Russia, the species Volgatitan simbirskiensis, composed by seven anterior and middle caudal vertebrae. With ages ranging the upper Hauterivian to Barremian, these taxa denotes the occurrence of a true titanosaurians in the earliest Cretaceous of Asia, raising several biogeographical implications, such as the timing and center of origin of the group, given the synchronous records in the southern Gondwana.

Finally, the problematic taxon Algoasaurus bauri (Broom 1904) from the Valanginian to Hauterivian Kirkwood Formation (Algoa Basin), South Africa, may represent the oldest Cretaceous titanosaurian known. This taxon is comprised by incomplete postcranial remains (e.g. opisthocoelian cervical and dorsal vertebrae, caudal vertebrae, ribs, scapula, femur and an ungual phalanx) unfortunately now lost (Broom 1904, McPhee et al. 2016). However, their fragmentary nature and the scarcity of coeval taxa hinders major comparisons. 
According McPhee et al. (2016) Algoasaurus has been considered possessing titanosaurian, diplodocoid (including rebbachisaurid) and camarasaurid affinities (Huene 1932, Jacobs et al. 1996, Canudo et al. 2003) and, actually, it is considered a nomen dubium by some authors (McIntosh 1990, Upchurch et al. 2004, McPhee et al. 2016), making Tapuiasaurus the most complete and the best-representative Early Cretaceous titanosaur known at this point.

Nonetheless, although Tapuiasaurus has been incorporated into numerous recent phylogenetic analyses (e.g. Zaher et al. 2011, Carballido \& Sander 2014, Gorscak et al. 2014, Lacovara et al. 2014, Poropat et al. 2015, Bandeira et al. 2016, González Riga et al. 2016, Martínez et al. 2016, Wilson et al. 2016, Averianov \& Skutschas 2017, Tykoski \& Fiorillo 2017, Carballido et al. 2017, Gorscak et al. 2017, Averianov \& Efimov 2018, González Riga et al. 2018, Sallam et al. 2018), its postcranial skeleton has not been previously fully described and illustrated in the literature.

Therefore, the present research aimed a full description of the postcranial osteology of Tapuiasaurus, comparing it with several other early titanosaurians. This study increases our knowledge of a key taxon, substantial to the understanding of the origins, phylogenetic relationships and first steps in titanosaurian diversification. Furthermore, this research also provides an increase in the understanding of the vertebrates that were present in the Sanfranciscana Basin during the Early Cretaceous, giving a solid basis for future paleoecological, biostratigraphical and paleobiogeographical studies.

\subsection{A brief review of titanosaurian anatomy, systematics and taxonomy}

Widespread and remarkably diverse, Titanosauria represents a successful lineage among sauropod dinosaurs (Curry Rogers 2005, Mannion et al. 2011, Carballido et al. 2017). Titanosauria constitutes a taxonomically numerous fossil group and, currently, comprises at least 100 valid species between the approximately 135 yet reported forms (Table 3.1.). According some authors (Curry Rogers 2005, Mannion et al. 2011) this diversity corresponds to more than a third of all sauropod dinosaur taxa described until now. The titanosaur records were present on entire Cretaceous time-interval, at rocks distributed throughout all the continents, including Antarctica (Wilson 2006a, Cerda et al. 2012). For this reason, this group represents a useful tool to studies regarding the Cretaceous paleobiogeography, as well as for stratigraphic correlations of continental deposits (Santucci 2005). 
Hugh Falconer in 1868 has made the first mention of titanosaur bones in the literature (Wilson \& Upchurch 2003), reporting the remains that later would represent the first named species of the group: Titanosaurus indicus Lydekker 1877. However, other mentions that correspond to titanosaurs or, at least, very close related taxa has been previously made, such as the occurrences of Aepisaurus elephantinus (Gervais 1848), Pelorosaurus (=Haestasaurus) becklesii (Mantell 1853, Upchurch et al. 2015), Hypselosaurus priscus (Matheron 1869), Eucamerotus foxii (Hulke 1871, Blows 1995) and Macrurosaurus semnus (Seeley 1876).

Lydekker (1877) established Titanosaurus indicus based on two mid-posterior caudal vertebrae and a left femur (Figures 1-2), recovered from the latest Cretaceous strata of Lameta Formation (India), basing its diagnosis only in the procoelous nature of the caudal remains. Posteriorly, Titanosauridae was erected to encompass the numerous taxa that also shared procoelous caudal vertebrae, making Titanosaurus the first dinosaur taxon with global distribution, since fourteen species have been referred to this genus, distributed across South America, Europe, Madagascar, India and Asia (Wilson \& Upchurch 2003, Wilson 2006a). This fact making "Titanosaurus indicus", as well as the subordinates that derives from it (Titanosauroidea, Titanosauridae and, Titanosaurinae) have long been recognized as a "wastebasket taxa" (Wilson 2006a).

Despite the numerous titanosaur discoveries has been made earlier in the history of dinosaur research, their relationships within other sauropods have long remained uncertain until the end of XX century, which began to be understood only in the late 1990s (Calvo \& Salgado 1995, Upchurch 1995, Salgado et al. 1997). Although non-cladistic, Huene (1929) made the first inference regarding the titanosaurian relationships (Figure 3), which hypothesized that titanosaurs compose the last lineage of the paraphyletic "Cetiosauridae", representing the descendants from this "basal stock" group (Huene 1929). This author also recognized Pleurocoelus as the "link" between cetiosaurids and titanosaurids (Salgado et al. 1997). As explained by Salgado et al. (1997), some authors disagree that hypothesis (Janensch 1929, Nopcsa 1930, Steel 1970, Kues et al. 1980), suggesting that titanosaurids are related to diplodocoids due the resemblance between the skull materials of Antarctosaurus and Diplodocus. 
This hypothesis has persisted for a long time, gaining ground mainly due the corroboration of the first cladistic studies involving sauropods (e.g. Gauthier 1986, McIntosh 1990). Upchurch (1995) consolidated this view (Figure 4) given the specific focus and inclusion of new cranial material on his analyses, such as the isolated skulls of Nemegtosaurus and Quaesitosaurus (Nowinski 1971, Kurzanov \& Bannikov 1983). Nonetheless, Calvo and Salgado (1995) in the same epoch recovered for the first time a different topology (Figure 5) in which titanosaurs and brachiosaurids representing a monophyletic group. It should be noted that, in this analysis, the authors did not include data from the Nemegtosaurus and Quaesitosaurus.

Salgado et al. (1997a) presented the first cladistic study with specific focus on titanosaurs. In this work, two equally most parsimonious trees were obtained, differing only in the position of Epachthosaurus and Malawisaurus. The strict consensus presented by these authors, depict Chubutisaurus as the sister group of Titanosauria, defined by only an unambiguous synapomorphy: the distal portion of the tibia wider transversely than anteroposteriorly. Brachiosaurus (= Giraffatitan) would correspond the sister-taxa of this clade, forming with Chubutisaurus and the other titanosaurs a group named of Titanosauriformes. This group would be supported by five synapomorphies: (1) midposterior caudal vertebrae with a neural arch occupying the anterior region of the center; (2) claw in the $1^{\text {st }}$ digit of the anterior limbs reduced or absent; (3) highly developed iliac preacetabular lobe; (4) pubic pedicel perpendicular to the sacral axis; (5) the presence of a lateral protuberance below the great trochanter of the femur (Figure 6). This hypothesis was corroborated by several subsequent studies (e.g. Sereno 1998, Upchurch 1998, Wilson \& Sereno 1998, Sanz et al. 1999), becoming widely accepted in the late 1990s.

Posteriorly, Wilson and Sereno (1998) identified in their analyses that titanosaurians would be more related to a more specific group of titanosauriforms from the Early Cretaceous, such as Euhelopus, Phuwiangosaurus and Chubutisaurus, than brachiosaurids, defining the most inclusive taxon Somphospondyli. The monophyly of Somphospondyli is mainly related to the pneumatization of the axial skeleton, being supported by the following synapomorphies: (1) cervical vertebrae with rudimentary laminae; (2) presacral vertebrae with spongy internal tissue (camellate or somphospondylous); (3) neural spine in the mid and posterior dorsal vertebrae inclined posteriorly; (4) medially deflected glenoid cavity on the scapula (Wilson \& Sereno 1998). This hypothesis (Figure 7) is widely accepted today, 
being recovered in several works (e.g. Carballido \& Sander 2014, González Riga et al. 2018).

Regarding to the taxonomy, titanosaurians have already been defined as a stem-based and a node-based clade (Table 3.2.). Bonaparte and Coria (1993) erected Titanosauria to allocate Titanosauridae and the newly denominate Andesauridae, without, however, provide a phylogenetic definition, only listing the taxa included and their respective synapomorphies. This latter would encompassing all species whose characteristics do not apply to the taxa traditionally included in Titanosauridae, such as medium and posterior amphyplatyan caudal vertebrae and presence of hyposphene-hypantrum complex in the dorsal vertebrae (i.e. Andesaurus, Malawisaurus, Argentinosaurus, and Epachthosaurus). Subsequently, Upchurch (1998) defined the stem-based clade Titanosauroidea to accommodate all taxa are more closely related to the "true" titanosaurians (e.g. Saltasaurus) in respect to the other titanosauriforms, such as brachiosaurids.

Nonetheless, in subsequent phylogenetic analyses (Salgado et al. 1997, Wilson \& Sereno 1998, Wilson 2002), Argentinosaurus and Epachthosaurus appear within Titanosauridae. Additionally, Titanosauridae was defined based on apomorphic characters, while Andesauridae is based only in plesiomorphic characters in which, by definition, explain it as a paraphyletic group (Wilson \& Upchurch 2003). Salgado et al (1997a) in their cladistic analysis, provide the first robust taxonomic definition for Titanosauria, and defines it as being a nodal clade composed by the most recent common ancestor of Andesaurus, Titanosauridae and all his descendants.

Sanz et al. (1999), provided a cladistic study in the description of the Spanish taxon Lirainosaurus. Some differences can be observed in the single tree most parsimonious obtained when compared with previous analyses (Santucci 2005). In the work of Sanz et al. (1999) the Asian Opisthocoelicaudia occupies a basal position in the cladogram. In other contributions (e.g. Wilson \& Sereno 1998), this taxon would be more related with saltasaurids, such as Saltasaurus and Neuquensaurus of Argentina. These authors also recovered a clade containing Haplocanthosaurus plus Andesaurus as sister-group of Titanosauroidea. Within Titanosauroidea, the authors have confirmed the titanosaurian monophyly, proposing the clade Eutitanosauria for a clade more derived titanosaurids, which is diagnosed, in part, by the presence of dermal armor. 
However, Wilson and Upchurch (2003) contested the validity of Titanosauridae. These authors pointed out that the name of the Family Titanosauridae, as well as the genus Titanosaurus and all derivatives of this (i.e. Titanosaurinae, Titanosauroidea) should be invalidated because the type species on which it was based, Titanosaurus indicus, is not diagnosable. Thus, posteriorly, Upchurch et al. (2004) attributed erected the clade Lithostrotia to encompasses the apomorphic titanosaurians, which consists in the node composed by the most recent common ancestor of Malawisaurus, Saltasaurus and all of his descendants. On the other hand, Salgado (2003) argues that the Phylogenetic Code of Biological Nomenclature (Phylocode) favours the maintenance of the term Titanosauridae. In attempt to stabilize and unify the taxonomy of Titanosauria, the author bases the group on a nodal definition. Additionally, the same author redefines other taxa, as Titanosauroidea, Eutitanosauria, Saltasaurinae and Opisthocoelicaudinae, as well as creating the stem-based clades Epachthosaurinae and Andesauroidea.

Upchurch et al. (2004) considered the absence of the hyposphene-hypantrum articulations in dorsal vertebrae as a synapomorphy for Lithostrotia that, along with other characteristics such as the strong procoelous caudal vertebrae supports the monophyly of the group. Additionally, Lithostrotia is sustained by other 12 Synapomorphies (see D'Emic, 2012), for example, opisthocoelous presacral vertebrae (with pneumatic cavities in the centra and neural arch) and the presence of osteoderms. Nonetheless, the presence of osteoderms in less derivatives taxa (such as Epachthosaurus and Opisthocoelicaudia) and its absence in some basal members of Lithostrotia (as Malawisaurus and Mendozasaurus), have led some authors to question the usage of the term, and reuse the Titanosauridae definition proposed by Salgado (2003). Further, this proposal is associated with the fact that the taxon name Lithostrotia is giving in a previously proposed synapomorphy of Eutitanosauria, indicating a probable synonymy.

In the last decade, the number of titanosaur discoveries, and consequently more complete species described, increased considerably, leading to the identification of several less inclusive clades (e.g. Franco Rosas et al. 2004, Calvo et al. 2007a and 2007b). This indicates a greater diversity and complexity in the internal titanosaurian phylogenetic relationships, in which most recovered topologies are conflicting, being solely some clades recovered in different data sets (Figure 8), and the synapomorphies that support the titanosaurian monophyly vary substantially in each topology (Figure 9). Moreover, mostly of these studies have been hindered by high missing data indexes, until the osteology of 
several titanosaurian species, as well as some important areas of the titanosaurian skeleton, remain poorly understood, particularly the skull, the most posterior caudal vertebrae, as well as the manual and pedal anatomy (González Riga et al. 2016). 


\subsection{Geologic settings}

\subsubsection{Sanfranciscana Basin stratigraphy}

The Sanfranciscana Basin (SFB) comprises in an Interior Sag (intracratonic unit sensu the terminology proposed by Kingston 1983), corresponding to the Phanerozoic sequence of the São Francisco-Congo Craton (Campos \& Dardenne 1997a, Bittencourt et al. 2015). This unit had its tectonic origin since the Paleozoic, with the formation of small rifts and grabens, whose the subsidence is intensified during the Lower Cretaceous due to distensive efforts in the Brazilian Shield occurred in the opening of the South Atlantic Ocean (Campos \& Dardenne 1997b, Silva et al. 2003).

This basin is elongated in-shape, with an axis in the N-S direction, and occupies a total area of $550,000 \mathrm{~km}^{2}$ that extends through the Piauí, Maranhão, Tocantins, Bahia, Goiás and Minas Gerais states (Sgarbi 1993, Campos \& Dardenne 1997a and 1997b). The SFB unit are delimited to the North by the Rio Preto Belt and the Paranamirim Aulacogen, to the East by the Araçuaí Belt and to the West by the Brasília Belt (Pires-Domingues 2009, Bittencourt et al. 2015). To the South, the Alto Paranaíba Uplift, besides delimiting the basin, contributed substantially to the deposition of the igneous units of the Upper Cretaceous sequence (Sgarbi et al. 2001).

The SFB (Figure 23) is divided into two restricted structural units, the Abaeté (to the south) and Urucuia (to the north) sub-basins, separated by a middle structural high, the Paracatu Uplift (Campos \& Dardenne 1997a and 1997b, Sgarbi et al. 2001, Pires-Domingues 2009, Bittencourt et al. 2015). Several stratigraphic charts were proposed for the sedimentary succession of SFB, assessed by traditional stratigraphic approaches (e.g. Sgarbi 1989, Campos \& Dardenne 1997b, Sgarbi et al. 2001) as well as by sequence stratigraphy (e.g. Kattah 1991, Mendonça 1999, 2003). This research followed the stratigraphy scheme proposed by Campos \& Dardenne (1997b) due his consensual lithologic and faciologic association, which are detailed below. According to these authors, the tectonic evolution of SFB consists of five sedimentary sequences, which are disconnected by regional unconformities.

The carbonatic Neoproterozoic units of the Bambuí Group represent the basement of the SFB. The basal unit consists of the Santa Fé Group, comprised by the Floresta and Tabuleiro Formations. Some authors (e.g. Kattah 1991, Kattah \& Carvalho 1997), however, consider invalid the inclusion of this group as part of SFB sedimentary sequence and regards 
the Areado Group as the basal unit. The Floresta and Tabuleiro formations are composed of diamictites, shales and massive sandstones with claystone intercalations, deposited under glaciogenic regime. These units may are correlated to the Itararé and Passa-Dois Groups of the Paraná Basin (Gondwana I Supersequence sensu Milani \& De Wit 2008) and the Balsas Group of the Parnaíba Basin, of Carboniferous-Permian age. Nevertheless, some authors suggests a Middle to Late Permian ages for these formations based in magnetostratigraphy data (Brandt \& Ernesto 2006).

The Cretaceous volcanosedimentary fill of the SFB is subdivided into the lower, Early Cretaceous Areado Group, and the upper, Late Cretaceous Urucuia and Mata da Corda Groups. The latter, is laterally interfingered with the top of Areado Group and includes alkaline lavas and volcaniclastic rocks (Zaher et al. 2011). The Lower Cretaceous Areado Group consists of the Abaeté (Late Valanginian- Early Barremian), Quiricó (Late Barremian-Early Aptian) and Três Barras (Late Aptian-Albian?) Formations. They represent a succession of interfingered sediments deposited under alluvial, braided-fluvial (Abaeté), lacustrine (Quiricó), aeolian and fluvial-deltaic cycles (Três Barras). The Areado group covers a large area of occurrence throughout the basin, since the south to north, being continuously in the Abaeté Sub-Basin and discontinuous in the Urucuia Sub-Basin (Campos \& Dardenne 1997). Most of the fossil record recovered in SFB is limited to the units of the Areado Group, mainly in the Quiricó Formation

The Abaeté Formation is divided into Carmo and Canabrava Members, represented mainly by conglomerates and massive sandstones, respectively, and deposited in alluvial and fluvial systems tracts under arid environments. The lacustrine Quiricó Formation is marked by intense variation of lacustrine lithologies, including mudstones, siltstones, marls, limestones, turbidites and shales intercalated by sandstones. The Três Barras Formation comprises mainly of through-cross-bedding sandstones deposited at successive system tracts (aeolian, fluvial and fluvial-deltaic). In this formation also occur a thin chert level intercalated with aeolian sandstones in the top of the sequence, indicative of a transgressive event (Kattah 1991, Arai 2000 and 2009).

The Urucuia Group, non-fossiliferous until now, is comprised mainly of aeolian sandstones deposited in a desert system from the south of the basin, being covered by epiclastic sediments in the northern portion. It is subdivided into the Posse and Serra das 
Araras Formations, which are probably correlated with the Araripe Basin fluvial-aeolian sequence represented by the Arajara and Exu Formations (Cenomanian).

The Mata da Corda Group, also non-fossiliferous, consists of the Patos and Capacete Formations. The first consists of ultramafic rocks of alkaline nature, while the second is represented by epiclastic and distal pyroclastic rocks deposited from volcanic sources with the contribution of an aeolian system. Finally, the Chapadão Formation, of PliocenePleistocene age, represents the Cenozoic cover and is composed of unconsolidated sediments, such as alluvial, colluvial and elluvial deposits (Silva et al. 2003, Bittencourt et al. 2015).

\subsubsection{Fossil record of Areado Group}

The fossil record of the Sanfranciscana Basin, specifically of Areado group (Table 3.3.), contrasts with the geographic and temporal range of this unit, which encompasses most of the entire Cretaceous interval. For a century, the only fossil occurrences from this unit consisted of palynomorphs and plants, mainly recovered from the shales deposits of Quiricó Formation. According to Bittencourt et al. (2015 and references therein) the first fossil discoveries at Areado Group were made by Liais (1872) represented by undetermined dicotyledoneous silicified logs. Later, Freyberg (1965) also reported other incomplete logs and referred to the genus Araucarioxylon, suggesting a Triassic age for the "Areado Sandstone" (op. cit.).

Duarte $(1968,1985 a, 1985 b, 1997)$ described gymnosperms and angiosperms from the Quiricó Formation black shale level, including, conifers of the genus Brachyphyllum obesum and Podozamites lanceolatus, the aquatic nymphaeaceae Nymphaeites choffatii and endemic poaceae Paraleptaspis varjensis. Except the later taxon, the remaining also occurs in several units from Northeastern of Brazil, such as Araripe (Crato and Romualdo Formations) and São Luís-Grajaú (Codó Formation) Basins.

Barbosa (1970), Lima (1979) and Arai et al. (1995) also identified several terrestrial palynomorph taxa in the black shale level, raising discussions about the age and environment of this unit.

Kattah (1991) registered the occurrence of a radiolarian fauna, dinoflagellates and sponge spicules in the chert level of Três Barras Formation. Posteriorly, from the samplings recovered in the same site, Dias-Brito and Pessagno (1996) identified the controversial 
radiolarian genera Parvincingula, Caneta and Noviforemanella, whose its distribution ranges from Kimmeridgian (Late Jurassic) to Valanginian (Early Cretaceous) ages, hence setting the underlying formations (Quiricó and Abaeté) into the Jurassic or the earliest Cretaceous, at least. Additionally, Dias-Brito et al. (1999) also identified some foraminiferans also from the same samples, including records of the genus Globigerinelloides.

From the black shale level of Quiricó Formation, several arthropod microfossil genera have been described, such as the spinicaudatans Cyzicus and Palaeolimnadiopsis (Rohn \& Cavalheiro 1996, Delicio et al. 1998) and the ostracodan genera Heterocypris, Eucyproides, Candonopsis, Harbinia, Cypridea, Bisulcocypris, Brasacypris, Ilyocypris, Darwinula and Wolburgiopsis (Barbosa et al. 1970, Carmo et al. 2004). Additional arthropodan fossils occurrences are represented by a solely record, of the endemic heteropteran Saucrolus silvai (Santos 1971).

Vertebrate records are scarcer and, for a long time, were represented only by two occurrences of the teleostean fishes: the gonorynchiform Dastilbe moraesi (a junior synonymous of $D$. crandalli) and the endemic osteoglossiform Laeliichthys ancestralis (Scorza \& Santos 1955, Santos 1985). Posteriorly, remains of coelacanthiforms were assigned to the Mawsonia gigas (Carvalho \& Maisey 2008). Other records include cephalic and fin spines associated with hybodontiforms sharks, amiid vertebrae, semiotitiform scales, isolated scales and a partial skeleton of a Lepisosteidae and, more recently, a dental plaque associated with a complete pterygopalatine bone of a Dipnoi, assignated to the genus Ceratodus (Carvalho \& Maisey 2008, Bittencourt et al. 2015 and 2017, De Carvalho 2017).

Carvalho and Kattah (1998) describes theropod and ornithopod dinosaur footprints in aeolian facies. The authors pointed that these ichnological records came from the basal portion of the sedimentary sequence, equivalent to the Abaeté Formation. However, Bittencourt et al. (2015) correlate this occurrence as belonging to the Três Barras Formation. Recently, undescribed sauropod tracks have also been reported, probably from the Três Barras Formation (Mescolotti 2017). Pires Domingues (2009) made the first mentions of dinosaur body-fossils. Alongside the titanosaurian specimens, Zaher et al. (2011) cited the presence of an abelisauroid theropod associated to the Tapuiasaurus skeleton. 
Additionally, Da Silva (2013) describes mesopodial and epipodial remains of another theropod right hindlimb with noasaurian affinities.

According to Bittencourt et al. (2015), some other dinosaur specimens from Quiricó Formation await for a detailed description. These isolated remains were recovered from the vicinities of the Coração de Jesus, in the Lagoa dos Patos and Ibiaí municipalities. They includes several isolated bone fragments (Vieira et al. 2015), as well as some isolated teeth were preliminary attributed to abelisaurids, carcharodontosaurids and dromaeosaurids (Carvalho et al. 2012, Santucci et al. 2014).

More recently, fragmentary remains of rebbachisaurids (a caudal neural spine and diapophysis), abelisaurid and carcharodontosaurid teeth are described for the Quiricó Formation (De Carvalho \& Santucci 2018).

\subsubsection{Reevaluation of the Quiricó Formation age}

The deposition age of the Cretaceous sequence of SFB possesses a debated history, as well as other Brazilian continental deposits, such as Bauru and Parecis Basins (Batezelli et al. 2017). Nevertheless, as explained by Zaher et al. (2011), the SFB were constrained by two remarkable magmatic events, at the bottom and top of the sedimentary sequence respectively, which are helpful to constrain the interval between the beginning and the end of sedimentation (Campos \& Dardenne 1997, Sgarbi 2001). The basal portion of this basin postdates the Paraná-Etendeka continental flood basalt event, dated at 138-128 My (Valanginian to Hauterivian time-interval, Turner et al. 1994). In the top, alkaline ultrabasic lavas and volcanoclastic rocks of Patos Formation, which possesses ages ranging from 9576 My (Cenomanian to Campanian) based on the K/Ar method (Hasui \& Cordani 1968, Sgarbi 2004, Riccomini 2005). The latter magmatic event are coeval to the Late Cretaceous sedimentation, which the volcanic rocks occurs intercalated with sandstones from the top of Mata da Corda Group (Sgarbi 2001). These ages are also contemporaneous to the magmatic activity occurring in Southeastern Brazil, relative to the Alto Paranaíba Uplift, that derives from the Trindade Mantle Plume Event (Thompson et al. 1998).

Until the last decade, only few macrofossils occurrences have been previously reported for the lacustrine deposits of the Quiricó Formation, hampering major biostratigraphical correlations. The fossil records that began to elucidate a more specific age for this formation, and the Cretaceous Sequence of SFB as well, was represented by the 
teleostean fishes remains recovered in limestones facies. They includes the ostariophysian Dastilbe moraesi (now a junior synonymous of D. crandalli sensu Brito \& Amaral 2008). The record of Dastilbe is important for biostratigraphic correlations, because it indicate for a first time a minimum Aptian age for these deposits. This taxon also occurs in other Brazilian units, such as the Codó (Parnaíba Basin), Crato (Araripe Basin) and Maceió formations (Sergipe-Alagoas Basin) with occurrences also in the Equatorial Guinea (Santos \& Carvalho 2004), indicative of a probable contemporaneity between these units (Carvalho \& Masey 2008, Bittencourt et al. 2015).

Bones of the coelacanthid sarcopterygian Mawsonia gigas were found at black shale facies (Carvalho \& Masey 2008). However, this taxon have an extensive temporal range (Berriasian to Cenomanian), incompatible with the volcanic ages that beacon the SFB (Zaher et al. 2011). In addition, other age-informative "fish" records from the top of Quiricó Formation includes a dental plaque associated with a pterygopalatine bone of a Dipnoi, which were assigned to the genus Ceratodus (De Carvalho 2017), This taxon have been also recorded in other Brazilian units, such as the Albian-Cenomanian Alcântara Formation (São Luís-Grajaú Basin).

Further, besides the previously reported dinosaur remains (Kattah \& Carvalho 1997, Zaher et al. 2011, Da Silva 2013), additional fragmentary specimens (e.g. rebbachisaurid bones and carcharodontosaurid teeth) has been described for the Quiricó Formation (De Carvalho \& Santucci 2018). These two dinosaur groups were typical faunal components of Early to "Mid-Cretaceous" (Aptian-Cenomanian) dinosaur communities, especially in North Africa and Argentina (Bittencourt \& Langer 2011 and 2012). Therefore, except for the Dastilbe occurrence, the vertebrate record of Quiricó Formation cannot constrain an age more restricted than the Early Cretaceous time-interval.

The micropaleontological data was useful to constrain specific ages for the dinosaurbearing beds of the Quiricó Formation (Figure 24), pointing this unit into the BarremianAptian boundary. Several arthropod microfossil genera have been described in claystones facies below and above of the black shale level at Carmo do Paranaíba and Rio do Sono localities. Them consists of the controversial-aging spinicaudatans Cyzicus and Palaeolimnadiopsis (Rohn \& Cavalero 1996, Delício 1998) and ten non-marine ostracodan genera (e.g. Heterocypris, Eucyproides, Candonopsis, Harbinia, Cypridea, Bisulcocypris, Brasacypris, Ilyocypris, Darwinula and Wolburgiopsis; Barbosa 1970, Carmo et al. 2004). 
The association of three ostracodans (Darwinula martinsi, Brasacypris sp. 1, and Harbinia symmetrica?) supports the Barremian-Aptian age, due these taxa have been previously recorded in Codó and Crato Formations. One of them (Brasacypris ovum), are earlier recognized from older units (the Neocomian Itaparica and Candeias formations of Recôncavo-Tucano Basin). Three others (Ilyocypris sp., Wolburgiopsis plastica and Wolburgiopsis chinamuertensis) were previous recovered from La Amarga Formation (Neuquén Basin), Argentina. The occurrence of Wolburgiopsis plastica and Wolburgiopsis chinamurtensis also supports a Barremian age for these deposits because they are restricted to this time-interval (Carmo et al. 2004).

Terrestrial palynomorph taxa have been also recovered from the black shale level of Quiricó Formation. Among them, the record of Transitoripollis (=Tucanopollis) crisopolensis palynozone supports the previous hypothesis of a Late Barremian maximum age, at least for this level of the Quiricó Formation (Lima 1979, Bittencourt et al. 2015), due this pollen disappeared in the mid-Aptian time-interval (Maysei 2000). Furthermore, the remarkable record of Afropollis, recovered from the upper levels above the Dastilbe site, suggests an Early Aptian age for the strata overlaying the black shale (Arai et al. 1995, Bittencourt et al. 2015). Additionally, the Quiricó Formation contains a high count of other angiosperm pollen grains characteristic of the Barremian-Aptian boundary (e.g. Sergipea cf. naviformis; Arai et al. 1995, Zaher et al. 2011).

\subsubsection{The Tapuiasaurus macedoi type locality}

According Pires Domingues (2009) and Zaher et al. (2011), in the region where Tapuiasaurus specimens coming (Figure 25), the Early Cretaceous Areado Group comprises, from the bottom to the top, into the Abaeté, Quiricó and Três Barras Formations. The Abaeté Formation at Coração de Jesus outcrops is represented by a thin, up to $8 \mathrm{~m}$ thick, package of conglomerate and sandstones deposited under alluvial fans to braided fluvial systems. The Quiricó Formation is present as a succession of typical lacustrine deposits, composed by claystones, siltstones, limestones and minor shale with sandstone intercalations facies, which reaches up to $100 \mathrm{~m}$ in thickness. The upper and overlaying Três Barras Formation is a thick, up to $140 \mathrm{~m}$, succession of aeolian, fluvial-deltaic and fluvial meandering sandstones and minor conglomeratic sandstones, with scarce centimetric peebles of quartz (op. cit.). 
The occurrence of the silt-clayey levels with convolute bedding, associated with calcrete horizons and sandstone lenses, led some authors to interpret that the lacustrine deposits of Coração de Jesus may represent a new lithostratigraphic unit (Pires Domingues 2009, Bittencourt et al. 2015). However, the presence of the Abaeté and Três Barras formations associated, at the base and overlaying respectively, confirms that these deposits are correlate with the Quiricó Formation. A possible explanation of the discrepant pattern of these levels from the typical Quiricó Formation lithology (e.g. shales and mudstones), consists of these levels represent deposits generated in the margin of the lacustrine body and the typical lithology of Quiricó Formation derived from basal levels of the lacustrine system, evidenced by the presence of black shale levels.

\subsubsection{Taphonomical remarks}

Pires Domingues (2009) has provided an extensive taphonomic study from the Quiricó Formation dinosaur-beds. The data obtained by this author indicate that the studied fossil accumulations in Coração de Jesus outcrops occur in alluvial fans sediments of a marginal lacustrine environment, representing an autochthonous concentration with possible temporal mixing. In the main outcrops were present sauropod and theropod associations (CJ01 and CJ-04). Tapuiasaurus has been found in the CJ-04 outcrop associated with an articulated abelisaurid theropod skeleton, found below its cervical series (Zaher et al. 2011).

According to Pires Domingues (2009), the direction and the dip of the bony elements indicates that the history of this accumulation included a prolonged biostratinomic phase, occurring the biodegradation of carcasses on the border of the lacustrine system (e.g. presence of drying cracks). A partial disarticulation of the skeletons of some individuals occured, especially those of large size, by biotic factors such as necrophagy (e.g. presence of teeth marks in long bones and ribs). Subsequently, there was partial burial and bone reorientation, mainly in the anterior and posterior limbs, by debris flows that reached the lacustrine system. The neck of Tapuiasaurus were found almost articulated (Figure 26), displaying the typical posteriorly turned rigor mortis, indicative that this part of the skeleton stay exposed from a determined period before the total burial. On the other hand, the base of the neck and rib cage of this individual is disposed in a chaotic way. The processes related to the fossil diagenesis included the plastic deformation of the bones due to the lithostatic pressure, the fracture of the bones due to the rearrangement of the deposits and, finally, the subaerial exposure and weathering by the current environment, causing some modules to be lost, such as the pelvis (Pires Domingues 2009). 


\section{2 - Objectives}

This research was divided into three main objectives:

(I) To describe in detail the postcranial skeleton of the holotype specimen of Tapuiasaurus macedoi (MZSP-PV 807), because it is the most complete titanosaur recovered in the Lower Cretaceous Quiricó Formation so far, and one of the most complete Early Cretaceous titanosaurs known to date;

(II) To compare the holotype specimen of Tapuiasaurus macedoi (MZSP-PV 807) with other individuals from the same locality and from coeval deposits, as well as with different taxa previously described for other Brazilian (e.g. Bauru Basin) and South American (e.g. Neuquén Basin) Cretaceous units;

(III) Submit the studied specimens to a cladistic analysis, in order to assess the phylogenetic relationships of Tapuiasaurus macedoi and the associated forms within Titanosauria, as well as to identify patterns in early titanosaurian evolution. 


\section{3 - Material and Methods}

\subsection{Material}

\subsubsection{Studied specimens}

The specimens whose constitute the study-object of this research, were collected in several field seasons, occurred between 2005 and 2012, in the vicinities of Coração de Jesus Municipality, northern region of Minas Gerais State (Pires Domingues 2009, Zaher et al. 2011, Silva 2013). These collecting campaigns were included in the scope of the thematic project "Evolution of reptile fauna in Southeastern Brazil from the Late Cretaceous to the Recent: paleontology, phylogeny and biogeography", under the coordination of Prof. Dr. Hussam El Dine Zaher and promoted by FAPESP - Fundação de Amparo à Pesquisa do Estado de São Paulo (Foundation for Research Support of the São Paulo State; grant 02/13602-4). The Table 3.4. presents the detailed list of all specimens collected and those that be used in this study.

\subsubsection{Specimens employed in comparisons}

The taxonomic sampling has chosen due their relevance to phylogenetic objectives of this study, and because they represent a set of taxa with the preservation of anatomical regions of interest as well. They are deposited in institutions in Brazil and Argentina (Table 3.5.). In addition, the specimens studied here has been also compared with taxa described in the literature that belongs to other localities (i.e. Africa-Madagascar, North America, Asia, Australia, Europe and India). Given the logistical limitations and the short period of thesis, these specimens should not be examined in person and were compared based on the published information (see cap. 3.4. on the volume II). 


\subsection{Methods}

\subsubsection{Osteological and directional terminology}

For anatomical and directional nomenclature, the traditional "Romerian" terminology have been chosen over the veterinarian and avian alternatives, as proposed by Wilson (2006a, 2012). In this nomenclature "anterior" and "posterior" were used as directional terms rather than the veterinarian alternatives "cranial" (or "rostral") and "caudal", and anatomical structures are standardized (e.g. "centrum" or "centra", not "corpus"). Additionally, the Romerian terminology considers the division of the vertebral bones into anterior, posterior, ventral, dorsal and lateral portions (left and right). Likewise, the appendicular bones (represented by propodial, mesopodial, metapodial and epipodial bones) are divided into the anterior, posterior, medial, lateral, proximal and distal portions.

Regarding to the identification and designation of vertebral laminae and fossae for Sauropoda (and other saurischian dinosaurs), was followed the landmark-based scheme proposed by Wilson $(1999,2012)$ and Wilson et al. (2011) respectively, with the addition of a few laminae suggested or redefined by other authors (Apesteguía 2005, Salgado \& Powell 2010, Gallina 2011). For internal pneumatic bony tissue arrangement, this study followed the nomenclature proposed by Wedel et al. (2000).

\subsubsection{Preparation and measurements of the specimens}

The excavation and recovering of the studied specimens followed the traditional procedures and techniques largely used in field campaigns, such as the jacketing process, plaster using, plaster bandage and tow (Feldmann 1989, Leiggi et al. 1994, May et al. 1994). A separating layer of toilet paper and aluminium foil were used to prevent the plaster from sticking to the fossil bones. Part of the skeleton was partially prepared in the field to determine the position and composition of each specimen, to ensure that all of it was entire collected. To protect and preserve the integrity of the bones was used the resin Paraloid b72 dissolved in acetone. The removal of rock matrix was done in the Laboratório de Paleontologia of the Museu de Zoologia of Universidade de São Paulo, Brazil, using several tools such as pneumatic hammers, air blasting systems, needles and pin vises. Measurements of the bone elements of the specimens were obtained using a digital calliper. Three acquisitions of each measure was taken in order to estimate a mean and avoid discrepant data. 


\subsubsection{Phylogenetic inference}

The methodology applied to determine phylogenetic relationships is the cladistics, following the parsimony principles enunciated by Hennig (1966) and Nelson and Platnick (1991). The character were structured and scored following the logical basis proposed by Sereno (2007), and polarized through outgroup comparisons (Farris 1982). An equally weighted parsimony analysis (Kluge \& Farris 1969, Farris 1970) were conducted using the software TNT v1.5, a program made freely available (www.lillo.org.ar/phylogeny/tnt) through the Willi Hennig Society (Goloboff et al. 2008, Goloboff \& Catalano 2016).

\subsubsection{Data matrix construction}

In order to assess the phylogenetic relationships of Tapuiasaurus within Titanosauria, the type specimen (MZSP-PV 807) were scored in the matrix of Carballido et al. (2017), because this dataset is currently one of the most comprehensive in number of characters and taxa of interest. Additionally, new unpublished characters were chosen to incorporate the data-set (see cap. VI on Volume II). The incorporation of new characters was made under the Character Distribution Map method, as suggested by Whitlock and Wilson (2013). The proportion of character data included from different anatomical modules can often have major impact on the tree topologies. This method is helpful to the identification of patterns in character inclusion by body region (Whitlock \& Wilson 2013).

\subsubsection{Operational Taxonomic Units scoring}

The Operational Taxonomic Units (OTUs) are equivalent to the studied specimens (specimen-level analysis), for this analysis that can incorporate and test phylogenetic signals derived from distinct morphological complexes. The taxa scoring are be done based on the suggestions made by Tschopp et al. (2017), in which an OTU consist of more than one specimen only when there a substantial anatomical overlap. The scoring of the studied specimens were made in the Mesquite software v3.6 (Maddison \& Maddison 2017).

\subsubsection{Heuristic tree search protocol}

Due the large sampling, were employed the more elaborate search procedures known as "New Technology Search" under the command 'xmult = consense5;'. A final round of TBR have been also performed to the best trees found during the replicates (command ' $b b$ '), in order to find all most parsimonious trees (MPTs). Unstable taxa in the MPTs were detected a priori using the "iterpcr" method in order to recover a reduced strict consensus that ignores the alternative positions of the highly fragmentary or unstable taxa (Pol \& Escapa 2009). 
The branch relative support for the MPT's has been calculated by statistical resampling methodologies, such as Bootstrap (Felsenstein 1985), and by the Decay Index or direct support measure method (Bremer 1994). Resultant trees were processed in FigTree (v.1.4.2).

\subsubsection{Taxonomy}

Since its first mention, over 150 years ago, Titanosauria had a complex taxonomic history (see Wilson \& Upchurch 2003, Wilson 2006b, Tykoski \& Fiorillo 2016). Recently, due the advance in inclusion of more complete taxa and well-structured characters into sauropod phylogenies, the identification of new titanosaurian clades generate several propositions of new names (e.g. Aeolosaurini, Rinconsauria, Lognkosauria, Lirainosaurinae; Salgado et al. 1997, Sereno 1998, Wilson \& Sereno 1998, Sanz et al. 1999, Franco Rosas et al. 2004, Calvo et al. 2007a and 2007b, Díez Díaz et al. 2018), as well as re-definitions and arguments to abandon or not previously established names (e.g. Titanosauridae; Wilson \& Upchurch 2003, Salgado 2003, Upchurch et al. 2004).

For this reason, this work compiled all taxonomic definitions yet proposed regarding to the titanosaur systematics (Table 3.2.) as well as of the immediate ancestor clades, in order to accommodate the recovered groups through the phylogenetic analysis. 


\section{6 - Conclusions}

1. Tapuiasaurus was previously diagnosed through 11 autapomorphies present in their cranial skeleton, as well as by an autapomorphic combination of characters which is revised here. In this study, four more putative autapomorphies are added to the skull and mandible diagnosis of this taxon;

2. Based on its postcranial skeleton, Tapuiasaurus is diagnosed by 12 additional putative autapomorphies that differentiates it from other titanosaurian taxa. Additionally, this taxon can be diagnosed by the unique autapomorphic combination of approximately 30 characters;

3. The phylogenetic analysis results, as well as the extensive osteological analysis of its postcranial skeleton, refute the hypothesis of Tapuiasaurus is deeply nested among advanced eutitanosaurian clades. This study recovered Tapuiasaurus as basal lithostrotian titanosaur, being more related to Early Cretaceous forms;

4. Through osteological comparisons, was identified that Tapuiasaurus shares eight synapomorphic characters with other two taxa (Yongjinglong and the Prata titanosaur), which was also recovered posteriorly by the phylogenetic analysis performed, supporting this clade by 11 additional synapomorphies. Here this group is provisionally named as Tapuiasaurinae. In addition, this study also recovered another group composed by endemic Brazilian titanosaurs, called as Trigonosaurinae, and supported by a unique combination of 11 characters;

5. The age of the Quiricó formation, unit that Tapuiasaurus comes, is reviewed here, in which it assumes a Barremian-Aptian age for these deposits;

6. Based on actual knowledge about titanosaur fossil record and paleogeographic data, true-titanosaurs already are well-dispersed at the beginning of Cretaceous, supporting a Late Jurassic cladogenesis for the group or, at least, at the Jurassic-Cretaceous boundary;

7. This study reveals that the stepwise acquisition of the typical titanosaurian characters possesses a mosaic pattern, in which the apomorphic anatomy presented by the advanced titanosaurians was acquired along the last part of the Late Cretaceous, probably in the post Turonian time-interval (89.8 My). 


\section{Resumo}

É apresentada aqui uma abrangente descrição do esqueleto pós-craniano e análise filogenética do titanossauro do Cretáceo Inferior Tapuiasaurus macedoi Zaher et al. 2011. Tapuiasaurus representa um táxon-chave devido à sua alta completude, lançando novas luzes nos primeiros passos na evolução dos titanossauros. As novas informações coletadas por este estudo revelam que a anatomia das vértebras pré-sacrais de Tapuiasaurus possui uma típica morfologia litoestrotiana apomórfica (e.g. espinhos neurais não divididos, ausência do complexo hiposfeno-hipantro e de processos aliformes), enquanto que a arquitetura dos membros anteriores e posteriores retém caracteres plesiomórficos, como a presença de falanges manuais, bem como um pé com alta contagem falangeana $(=10)$. Contrariando estudos anteriores, a análise filogenética realizada recuperou Tapuiasaurus como um litoestrotia basal, táxon-irmão do grupo formado por Yongjinglong datangi, do Cretáceo Inferior da China, mais um táxon relictual não nomeado do Cretáceo Superior do Estado de Minas Gerais, a mesma região geográfica na qual Tapuiasaurus provém. O novo clado reconhecido representaria uma das primeiras irradiações de litoestrotios em todo o mundo, fornecendo dados adicionais que ajudarão a elucidar os padrões de dispersão do grupo. Este estudo revela que a aquisição dos caracteres titanossaurianos típicos foi gradual, possuindo um padrão de mosaico, no qual a anatomia apomórfica apresentada pelos titanossauros avançados foi adquirida ao longo da última parte do Cretáceo Superior, provavelmente a partir do intervalo pós-Turoniano (89,8 M).

Palavras-chave: Cretáceo Inferior, Titanosauria, Tapuiasaurus macedoi, Osteologia, Filogenia. 


\section{Abstract}

Herein is presented a comprehensive description of the postcranial skeleton and phylogenetic analysis of the Early Cretaceous titanosaurian Tapuiasaurus macedoi Zaher et al. 2011. Tapuiasaurus becomes a key-taxon due its completeness, shedding new lights on the first steps in the early titanosaur evolution. The new information gathered by this study reveals that the presacral vertebrae anatomy of Tapuiasaurus possesses the typical apomorphic lithostrotian morphology (e.g. single neural spines, absence of hyposphenehypantrum complex and aliform processes), whereas the architecture of fore and hindlimbs retains plesiomorphic characters, such as the presence of manual phalanges, as well as a pes with greater phalangeal count $(=10)$. Contrasting with previous studies, the phylogenetic analysis retrieved Tapuiasaurus as an early lithostrotian, sister-taxon of the group formed by Yongjinglong datangi, from the Early Cretaceous of China, plus a relictual unnamed taxon from the Late Cretaceous of Minas Gerais State, the same region that in which Tapuiasaurus comes. The new recognized clade that would represents one of the first lithostrotian irradiations around the world, providing additional data that will help elucidate dispersion patterns in the group. This study reveals that the stepwise acquisition of the typical titanosaurian characters possesses a mosaic pattern, in which the apomorphic anatomy presented by the advanced titanosaurians was acquired along the last part of the Late Cretaceous, probably in the post Turonian time-interval (89.8 My).

Key-words: Early Cretaceous, Titanosauria, Tapuiasaurus macedoi, Osteology, Phylogeny. 


\section{References}

Allain, R., \& Aquesbi, N. (2008). Anatomy and phylogenetic relationships of Tazoudasaurus naimi (Dinosauria, Sauropoda) from the late Early Jurassic of Morocco. Geodiversitas, 30(2), 345-424.

Allain, R., Taquet, P., Battail, B., Dejax, J., Richir, P., Véran, M., [...] \& Khenthavong, B. (1999). Un nouveau genre de dinosaure sauropode de la formation des Grès supérieurs (Aptien-Albien) du Laos. Comptes Rendus de l'Académie des Sciences-Series IIAEarth and Planetary Science, 329(8), 609-616.

Apesteguía, S. (2004). Bonitasaura salgadoi gen. et sp. nov.: a beaked sauropod from the Late Cretaceous of Patagonia. Naturwissenschaften, 91(10), 493-497.

Arai, M., Dino, R., Milhomem, P. S., \& Sgarbi, G. N. C. (1995). Micropaleontologia da Formação Areado, Cretáceo da Bacia Sanfranciscana: estudos de ostracodes e palinologia. In Anais do 14u Congresso Brasileiro de Paleontologia. Uberaba: Sociedade Brasileira de Paleontologia (pp. 2-3).

Arid, F. M. \& Vizotto, L. D. (1971). Antarctosaurus brasiliensis, um novo Saurópodo do Cretáceo Superior do Sul do Brasil. In: Congresso Brasileiro De Geologia, 25, São Paulo. Anais... São Paulo: Sociedade Brasileira De Geologia/Núcleo SP, 297-305.

Arid, F. M.; Vizotto, L. D. \& Landim, P. M. B. A. (1962). Ocorrência de um jazigo fossilífero nos arredores de São José Do Rio Preto. Ciência E Cultura, 14 (3): p.172.

Arid, F. M. \& Vizotto, L. D. (1963). Sobre vertebrados fósseis do município de Ibirá, São Paulo. Ciência E Cultura, 15 (3): p.181.

Averianov, A. \& Skutschas, P. (2017). A new lithostrotian titanosaur (Dinosauria, Sauropoda) from the Early Cretaceous of Transbaikalia. Russia. Biological Communications, 62(1), 6-18.

Averianov, A., \& Efimov, V. (2018). The oldest titanosaurian sauropod of the Northern Hemisphere. Biological Communications, 63(3), 145-162. 
Bandeira, K. L., Simbras, F. M., Machado, E. B., Campos, D. A., Oliveira, G. R. \& Kellner, A. W. (2016). A new giant Titanosauria (Dinosauria: Sauropoda) from the Late Cretaceous Bauru Group, Brazil. PloS One, 11(10), e0163373.

Bedell, M. W. Jr. \& Trexler, D. L. (2005) First articulated manus of Diplodocus carnegii in Thunder-lizards: the sauropodomorph dinosaurs (eds Tidwell, V. \& Carpenter, K.) Ch. 14, 302-320 (Indiana University Press)

Bertini, R. J. \& Campos, D. A. (1987). Restos de um grande saurópodo em Monte Alto, Estado de São Paulo. Em: Congresso Brasileiro De Paleontologia, 10, Rio de Janeiro, Resumos Das Comunicações. Rio de Janeiro: Sociedade Brasileira De Paleontologia, p.10.

Bittencourt, J. S., Gallo, V., \& Rodrigues, G. A. (2017). Lepisosteoid-type fish scales in the Barremian-Aptian (Lower Cretaceous) of the Sanfranciscana Basin, Southeastern Brazil. Cretaceous Research, 70, 1-7.

Bittencourt, J. S., Kuchenbecker, M., Vasconcelos, A. G., \& Meyer, K. E. (2015). O registro fóssil das coberturas sedimentares do Cráton do São Francisco em Minas Gerais. Revista Geonomos, 23(2).

Bittencourt, J. S., Langer, M. C. (2011). Os dinossauros no Mesozóico brasileiro e as relações biogeográficas entre África e América do Sul. In: Gallo, V.; Silva, H. M. A.; Brito, P. M.; Figueiredo, F. J. (Orgs); Paleontologia De Vertebrados: Relações Entre América Do Sul E África, Interciência, Rio De Janeiro, p.301-332.

Blows, W. T. (1995). The early Cretaceous brachiosaurid dinosaurs Ornithopsis and Eucamerotus from the Isle of Wight, England. Palaeontology, 38(1), 187-198.

Bonaparte, J. F. (1996). Cretaceous tetrapods of Argentina. Münchner Geowissenschaftliche Abhandlungen, 30, 73-130.

Bonaparte, J. F., \& Coria, R. A. (1993). Un nuevo y gigantesco saurópodo titanosaurio de la Formación Río Limay (Albiano-Cenomaniano) de la Provincia del Neuquén, Argentina. Ameghiniana, 30(3), 271-282.

Bonaparte, J. F., \& Powell, J. E. (1980). A continental assemblage of tetrapods from the Upper Cretaceous beds of El Brete, northwestern Argentina (Sauropoda-CoelurosauriaCarnosauria-Aves). Memoires de la Societe Geologique de France, 139: p.19-28. 1980. 
Bonaparte, J. F., Heinrich, W. D. \& Wild, R. (2000). Review of Janenschia Wild, with the description of a new sauropod from the Tendaguru beds of Tanzania and a discussion on the systematic value of procoleous caudal vertebrae in the sauropoda. Palaeontographica Abteilung A, 25-76.

Bonaparte, J. F., Riga, B. J. G., \& Apesteguía, S. (2006). Ligabuesaurus leanzai gen. et sp. Nov. (Dinosauria, Sauropoda), a new titanosaur from the Lohan Cura Formation (Aptian, lower Cretaceous) of Neuquén, Patagonia, Argentina. Cretaceous Research, 27(3), 364376.

Borsuk-Bialynicka, M. (1977). A new camarasaurid sauropod Opisthocoelicaudia skarzynskii gen. n., sp. n. from the Upper Cretaceous of Mongolia. Palaeontologia Polonica, 37(5), 5-64.

Broom, R. (1904). V. On the Occurrence of an Opisthocœlian Dinosaur (Algoasaurus bauri) in the Cretaceous Beds of South Africa. Geological Magazine, 1(9), 445-447.

Calvo J.O., Porfiri J.D., González Riga B.J. \& Kellner A.W.A. (2007a). A new Cretaceous terrestrial ecosystem from Gondwana with the description of a new sauropod dinosaur. Anais da Academia Brasileira de Ciências. 79, 529- 541.

Calvo J.O., Porfiri J.D., González Riga B.J., Kellner A.W.A. (2007c). Anatomy of Futalognkosaurus dukei Calvo, Porfiri, Gonza'lez Riga \& Kellner, 2007 (Dinosauria, Titanosauridae) from the Neuquén Group (Late Cretaceous), Patagonia, Argentina. Arquivos do Museu Nacional, Rio de Janeiro 65, 511 - 526.

Calvo, J. O., \& Bonaparte, J. F. (1991). Andesaurus delgadoi gen. et. sp. nov.(SaurischiaSauropoda), dinosaurio Titanosauridae de la Formacion Rio Limay (AlbianoCenomaniano), Neuquen, Argentina. Ameghiniana, 28, 303-310.

Calvo, J. O., \& González Riga, B. J. (2003). Rinconsaurus caudamirus gen. et sp. nov., a new titanosaurid (Dinosauria, Sauropoda) from the Late Cretaceous of Patagonia, Argentina. Revista geologica de Chile, 30(2), 333-353.

Calvo, J. O., \& Salgado, L. (1995). Rebbachisaurus tessonei sp. nov. a new Sauropoda from the Albian-Cenomanian of Argentina; new evidence on the origin of the Diplodocidae. Gaia, 11, 13-33. 
Calvo, J. O., González Riga, B. J., \& Porfiri, J. D. (2007b). A new titanosaur sauropod from the Late Cretaceous of Neuquén, Patagonia, Argentina. Arquivos do Museu Nacional, 65(4), 485-504.

Campos, D. D. A., Kellner, A. W., Bertini, R. J., \& Santucci, R. M. (2005). On a titanosaurid (Dinosauria, Sauropoda) vertebral column from the Bauru group, Late Cretaceous of Brazil. Arquivos do Museu Nacional, 63(3), 565-593.

Canudo, J., Salgado, L., Pérez Lorente, F. (2003). Los dinosaurios del Neocomiense (Cretácico inferior) de la Península Ibérica y Gondwana occidental: implicaciones paleobiogeográficas. In Dinosaurios y otros reptiles mesozoicos en Espana (pp. 251268). Universidad de La Rioja.

Carballido J.L., Salgado, L., Pol D., Canudo J.I., Garrido A. (2012). A new basal rebbachisaurid (Sauropoda, Diplodocoidea) from the Early Cretaceous of the Neuquén Basin; evolution and biogeography of the group. Historical Biology 24, 631- 654 . (doi:10.1080/08912963.2012.672416)

Carballido, J. L., \& Sander, P. M. (2014). Postcranial axial skeleton of Europasaurus holgeri (Dinosauria, Sauropoda) from the Upper Jurassic of Germany: implications for sauropod ontogeny and phylogenetic relationships of basal Macronaria. Journal of Systematic Palaeontology, 12(3), 335-387.

Carballido, J. L., Pol, D., Cerda, I., \& Salgado, L. (2011). The osteology of Chubutisaurus insignis del Corro, 1975 (Dinosauria: Neosauropoda) from the 'middle'Cretaceous of central Patagonia, Argentina. Journal of Vertebrate Paleontology, 31(1), 93-110.

Carballido, J. L., Pol, D., Otero, A., Cerda, I. A., Salgado, L., Garrido, A. C., Ramezani, J., Cúneo, N. R. \& Krause, J. M. (2017). A new giant titanosaur sheds light on body mass evolution among sauropod dinosaurs. Proceedings of the Royal Society B, 284(1860), 20171219.

Carballido, J. L., Pol, D., Parra Ruge, M. L., Padilla Bernal, S., Páramo-Fonseca, M. E., \& Etayo-Serna, F. (2015). A new Early Cretaceous brachiosaurid (Dinosauria, Neosauropoda) from northwestern Gondwana (Villa de Leiva, Colombia). Journal of Vertebrate Paleontology, 35(5), e980505. 
Carvalho, A.B., Zaher, H., da Silva, R.R., Nascimento, P.M. (2012). Análise morfológica dos dentes de terópodes (Dinosauria: Saurischia) da Formação Quiricó, Eocretáceo da Bacia Sanfranciscana, estado de Minas Gerais. In: VIII simpósio Brasileiro de Paleontologia de Vertebrados, Boletim de Resumos, Recife, p. 109.

Carvalho, I. S., \& Kattah, S. S. (1998). As pegadas fósseis do paleodeserto da Bacia Sanfranciscana (Jurássico superior-Cretáceo inferior, Minas Gerais). Anais da Academia Brasileira de Ciências, 70(1), 53-67.

Carvalho, I. S., Salgado, L., Lindoso, R. M., Araújo-Júnior, H. I., Nogueira, F. C. C. \& Soares, J. A. (2017). A new basal titanosaur (Dinosauria, Sauropoda) from the Lower Cretaceous of Brazil. Journal of South American Earth Sciences, 75, 74-84.

Carvalho, I.S., Bertolino, L.C., Borghi, L.F., Duarte, L., Carvalho, M.S.S., Cassab, R.C.T. (1994). Range charts of the fossils of the Cretaceous interior basins - The São Francisco Basin, In: Stratigraphic range of Cretaceous mega- and microfossils of Brazil, Beurlen, G., Campos, D.A., Viviers, M.C. (Eds.), UFRJ, Rio de Janeiro, pp. 333-352.

Carvalho, J. C. D. Vertebrados fósseis da Formação Quiricó, Cretáceo Inferior da Bacia Sanfranciscana. Dissertação (mestrado)-Universidade de Brasília, Instituto de Geociências, Programa de Pós-Graduação em Geologia, 2017. 104p.

Casal, G., Martínez, R., Luna, M., Sciutto, J. C., \& Lamanna, M. (2007). Aeolosaurus colhuehuapensis sp. nov.(Sauropoda, Titanosauria) de la Formación Bajo Barreal, Cretácico Superior de Argentina. Revista Brasileira de Paleontologia, 10(1), 53-62.

Cerda, I. A., Carabajal, A. P., Salgado, L., Coria, R. A., Reguero, M. A., Tambussi, C. P., \& Moly, J. J. (2012). The first record of a sauropod dinosaur from Antarctica. Naturwissenschaften, 99(1), 83-87.

Coria, R. A., Filippi, L. S., Chiappe, L. M., Garcia, R., \& Arcucci, A. B. (2013). Overosaurus paradasorum gen. et sp. nov., a new sauropod dinosaur (Titanosauria: Lithostrotia) from the Late Cretaceous of Neuquén, Patagonia, Argentina. Zootaxa, 3683(4), 357-376. 
Cunha, F. L. S., Rêgo, D. D., Capilla, R. (1987). Nova Ocorrência De Répteis Cretácicos, No “Sítio Myzobuchi”, Da Formação Baurú, Em Álvares Machado, Sp. Em: Congresso Brasileiro De Paleontologia, 10, Anais. Rio De Janeiro. Rio De Janeiro, 1, P.143-154.

Curry Rogers, K. (2009). The postcranial osteology of Rapetosaurus krausei (Sauropoda: Titanosauria) from the Late Cretaceous of Madagascar. Journal of vertebrate Paleontology, 29(4), 1046-1086.

Curry Rogers, K. A. (2005). Titanosauria: a phylogenetic overview: in KA Curry Rogers and JA Wilson (eds.). The Sauropods: Evolution and Paleobiology, University of California Press, pp. 50-103.

Curry-Rogers, K. \& Forster, C. A. (2001). The last of the dinosaur titans: a new sauropod from Madagascar. Nature, 412(6846), 530.

Curry-Rogers, K. \& Forster, C. A. (2004). The skull of Rapetosaurus krausei (Sauropoda: Titanosauria) from the Late Cretaceous of Madagascar. Journal of Vertebrate Paleontology, 24(1), 121-144.

D’Emic M.D. (2012). The early evolution of titanosauriform sauropod dinosaurs. Zool. J. Linn. Soc. 166, 624- 671. (doi:10.1111/j.1096-3642.2012.00853.x)

D’emic, M. D., Wilson, J. A., \& Williamson, T. E. (2011). A sauropod dinosaur pes from the latest Cretaceous of North America and the validity of Alamosaurus sanjuanensis (Sauropoda, Titanosauria). Journal of Vertebrate Paleontology, 31(5), 1072-1079.

Da Silva, R. R. (2013). Descrição osteológica e posicionamento filogenético de um terópode (Dinosauria, Saurischia) do Cretáceo Inferior da Bacia Sanfranciscana, município de Coração de Jesus, Minas Gerais, Brasil. MSc. dissertation, Universidade de São Paulo. $121 \mathrm{p}$.

De Carvalho, J. C., \& Santucci, R. M. (2018). New dinosaur remains from the Quiricó Formation, Sanfranciscana Basin (Lower Cretaceous), Southwestern Brazil. Cretaceous Research, 85, 20-27.

De Carvalho, M. S., \& Maisey, J. G. (2008). New occurrence of Mawsonia (Sarcopterygii: Actinistia) from the Early Cretaceous of the Sanfranciscana Basin, Minas Gerais, southeastern Brazil. Geological Society, London, Special Publications, 295(1), 109-144. 
Delicio, M. P., Barbosa, E. M., Coimbra, J. C., \& Vilella, R. A. (1998). Ocorrência de conchostráceos e ostracodes em sedimentos pós-paleozóicos da Bacia Alto SanfranciscoOlhos d'Agua, noroeste de Minas Gerais. Acta Geologica Leopoldensia, 21, 13-20.

Derby, O. A. (1895). Notas sobre a geologia e paleontologia de Matto Grosso. Arquivos do Museu Nacional, 9: p.59-88.

Dias Brito, D., Pessagno Jr, E. A., \& Castro, J. C. (1999). Novas considerações cronoestratigráficas sobre o silexito a radiolários do sul da Bacia Sanfranciscana, Brasil, e a ocorrência de foraminíferos planctônicos nestes depósitos. Simpósio sobre o Cretáceo do Brasil, 5, 567-575.

Díez Díaz, V., Garcia, G., Pereda Suberbiola, X., Jentgen, B., Stein, K., Godefroit, P., \& Valentin, X. (2018). The titanosaurian dinosaur Atsinganosaurus velauciensis (Sauropoda) from the Upper Cretaceous of southern France: new material, phylogenetic affinities, and palaeobiogeographical implications. Cretaceous Research, 91.

Do Carmo, D. A., Tomassi, H. Z., \& De Oliveira, S. B. S. G. (2004). Taxonomia e distribuicao estratigrafica dos ostracodes da formacao Quirico, grupo Areado (Cretaceo Inferior), bacia Sanfranciscana, Brasil. Revista Brasileira de Paleontologia, 7(2), 139149.

Duarte, L. (1968). Restos vegetais fósseis da Formação Areado. In: XXII Congresso Brasileiro de Geologia, Anais, Belo Horizonte, p. 68.

Duarte, L. (1985a). Vegetais fósseis da Chapada do Araripe, In: Coletânea de Trabalhos Paleontológicos, Campos, D.A., Ferreira, C.S., Brito, I.M., Viana, C.F. (Eds.). DNPM, Rio de Janeiro, pp. 557-563.

Duarte, L., (1985b). Vegetais fósseis da Formação Areado, município de Presidente Olegário, Minas Gerais. In: $9^{\mathbf{0}}$ Congresso Brasileiro de Paleontologia, Resumos, Fortaleza, p. 59.

Duarte, L., (1997). Vegetais do Cretáceo Inferior (Aptiano) da Formação Areado, município de Presidente Olegário, Estado de Minas Gerais. Anais da Academia Brasileira de Ciências 69, 495-503. 
Falconer, H. 1868. Notes on fossil remains found in the Valley of the Indus below Attock, and at Jubbulpoor. In Palaeontological Memoirs and Notes of the late Hugh Falconer, vol. I. Fauna Antiqua Sivalensis., Edited by: Murchison, C. vol. I, 414419. London: Robert Hardwicke.

Feng, T., Jin, X., \& Kang, X. (Eds.). (2001). Omeisaurus maoianus: a complete Sauropoda from Jingyan, Sichuan. China Ocean Press.

Filippi, L. S., \& Garrido, A. C. (2008). Pitekunsaurus macayai gen. et sp. nov., nuevo titanosaurio (Saurischia, Sauropoda) del Cretácico Superior de la Cuenca Neuquina, Argentina. Ameghiniana, 45(3), 575-590.

Filippi, L. S., Salgado, L., \& Garrido, A. C. (2019). A new giant basal titanosaur sauropod in the Upper Cretaceous (Coniacian) of the Neuquén Basin, Argentina. Cretaceous Research.

França, M. A., Júlio, C. D. A., Riff, D., Hsiou, A. S., \& Langer, M. C. (2016). New lower jaw and teeth referred to Maxakalisaurus topai (Titanosauria: Aeolosaurini) and their implications for the phylogeny of titanosaurid sauropods. PeerJ, 4, e2054.

Franco-Rosas, A. C., Salgado, L. , Rosas, C. F., \& Carvalho, I. D. S. (2004). Nuevos materiales de titanosaurios (Sauropoda) en el Cretácico superior de Mato Grosso, Brasil. Revista Brasileira de Paleontologia, 7(3), 329-336.

Freyberg, B.v. (1965). Resultado das pesquisas geológicas em Minas Gerais. In: XIX Congresso Brasileiro de Geologia, Anais, Rio de Janeiro, p. 156-211.

Gallina PA, Apesteguía S. (2011) Cranial anatomy and phylogenetic position of the titanosaurian sauropod Bonitasaura salgadoi. Acta Palaeontol. Pol. 56, 45 - 60. (doi:10.4202/app.2010.0011)

Gallina, P. A. (2011). Notes on the axial skeleton of the titanosaur Bonitasaura salgadoi (Dinosauria-Sauropoda). Anais da Academia Brasileira de Ciências, 83(1), 235-246.

Gallina, P. A., \& Apesteguía, S. (2015). Postcranial anatomy of Bonitasaura salgadoi (Sauropoda, Titanosauria) from the Late Cretaceous of Patagonia. Journal of Vertebrate Paleontology, 35(3), e924957. 
Gauthier J (1986) Saurischian monophyly and the origin of birds. In: Padian K (ed) The origin of birds and the evolution of flight. Memoirs of the California Academy of Sciences, no. 8, pp 1-55

Gervais P. 1848-1852. — Zoologie et Paléontologie françaises. Arthus Bertrand, Paris, $271 \mathrm{p}$.

Ghilardi, A. M., Aureliano, T., Duque, R. R., Fernandes, M. A., Barreto, A. M. \& Chinsamy, A. (2016). A new titanosaur from the Lower Cretaceous of Brazil. Cretaceous Research, 67, 16-24.

Gilmore, C. W. (1932). On a newly mounted skeleton of Diplodocus in the United States National Museum. Proceedings of the United States National Museum.

Gilmore, C. W. (1933). Two new dinosaurian reptiles from Mongolia: with notes on some fragmentary specimens. American Museum novitates; no. 679.

Gilmore, C. W. (1936). Osteology of Apatosaurus, with Species Reference to Specimens in the Carnegie Museum. Carnegie Institute (Vol. 11, No. 4).

Gilmore, C. W. (1946). Reptilian fauna of the North Horn Formation of central Utah (Vol. 210). US Government Printing Office.

Gilmore, C. W. (1922). A new sauropod dinosaur from the Ojo Alamo Formation of New Mexico. Smithsonian Miscellaneous Collections 72:1-9.

Gomani, E. M. (2005). Sauropod dinosaurs from the early Cretaceous of Malawi, Africa. Palaeontologia Electronica, 8(1), 27A.

González Riga, B. J. \& Ortiz, L. D. (2014). A new titanosaur (Dinosauria, Sauropoda) from the Upper Cretaceous (Cerro Lisandro Formation) of Mendoza Province, Argentina. Ameghiniana, 51(1), 3-25. doi:10.5710/AMEGH.26.12.1013.1889

González Riga, B. J. (2003). A new titanosaur (Dinosauria, Sauropoda) from the Upper Cretaceous of Mendoza province, Argentina. Ameghiniana, 40(2), 155-172. 
González Riga, B. J., Calvo, J. O. \& Porfiri, J. (2008). An articulated titanosaur from Patagonia (Argentina): new evidence of neosauropod pedal evolution. Palaeoworld, 17(1), $33-40$.

González Riga, B. J., Lamanna, M. C., David, L. D. O., Calvo, J. O. \& Coria, J. P. (2016). A gigantic new dinosaur from Argentina and the evolution of the sauropod hind foot. Scientific Reports, 6, 19165.

González Riga, B. J., Mannion, P. D., Poropat, S. F., Ortiz David, L. D., \& Coria, J. P. (2018). Osteology of the Late Cretaceous Argentinean sauropod dinosaur Mendozasaurus neguyelap: implications for basal titanosaur relationships. Zoological Journal of the Linnean Society, 184(1), 136-181.

González Riga, B. J., Previtera, E., \& Pirrone, C. A. (2009). Malarguesaurus florenciae gen. et sp. nov., a new titanosauriform (Dinosauria, Sauropoda) from the Upper Cretaceous of Mendoza, Argentina. Cretaceous Research, 30(1), 135-148.

Gorscak, E. (2016). Descriptive and Comparative Morphology of African Titanosaurian Sauropods: New Information on the Evolution of Cretaceous African Continental Faunas (Doctoral dissertation, Ohio University).

Gorscak, E., \& O’Connor, P. M. (2019). A new African Titanosaurian Sauropod Dinosaur from the middle Cretaceous Galula Formation (Mtuka Member), Rukwa Rift Basin, Southwestern Tanzania. PloS one, 14(2), e0211412.

Gorscak, E., O'Connor, P. M., Roberts, E. M., \& Stevens, N. J. (2017). The second titanosaurian (Dinosauria: Sauropoda) from the middle Cretaceous Galula Formation, southwestern Tanzania, with remarks on African titanosaurian diversity. Journal of Vertebrate Paleontology, 37(4), e1343250.

Gorscak, E., O'Connor, P. M., Stevens, N. J. \& Roberts, E. M. (2014). The basal titanosaurian Rukwatitan bisepultus (Dinosauria, Sauropoda) from the middle Cretaceous Galula Formation, Rukwa Rift Basin, southwestern Tanzania. Journal of Vertebrate Paleontology, 34(5), 1133-1154. 
Harris, J. D. (2006). The significance of Suuwassea emilieae (Dinosauria: Sauropoda) for flagellicaudatan intrarelationships and evolution. Journal of Systematic Palaeontology, $4(2), 185-198$.

He, X.-L., Li, K., Cai, K.-J. \& Gao, Y.-H. (1988) [Omeisaurus tianfuensis-a new species of Omeisaurus from Dashanpu, Zigong, Sichuan.] J. Chengdu Geol. Suppl. 2, 13-32. [In Chinese with English summary.]

Huene, F. R. F. (1932). Die Fossile Reptil-ordnung Saurischia: Ihre Entwicklung und Geschichte. Gebrüder Borntraeger.

Huene, F. Von (1931). Verschiedene Mesozoisches Wirbeltierreste Aus Südamerika. Neues Jahrbuch Fur Mineralogie, Geologie Und Paläontologie, Beilage-Band, 66 (B): p.181-191.

Huene, F. (1929). Los saurisquios y ornitisquios del Cretáceo Argentino. Anales del Museo de La Plata, 3: 1-196.

Hulke, J. W. (1871). Note on the Os Pubis and Ischium of Ornithopsis eucamerotus. Quarterly Journal of the Geological Society, 38(1-4), 372-376.

Jacobs, L. L., Winkler, D. A., \& Gomani, E. M. (1996). Cretaceous dinosaurs of Africa: examples from Cameroon and Malawi. Memoirs-Queensland Museum, 39, 595-610.

Jain, S. L., \& Bandyopadhyay, S. (1997). New titanosaurid (Dinosauria: Sauropoda) from the Late Cretaceous of central India. Journal of Vertebrate Paleontology, 17(1), 114136.

Janensch, W. (1914). Ubersicht uber die Wirbeltierfauna der Tendaguru-Schichten, nebst einer kurzen Charakterasierung der neu aufgestellten Arten von Sauropoden. Archiv fur Biontologie, 3, 81-110.

Janensch, W. 1929. Die Wirbelsäule der Gattung Dicraeosaurus. Palaeontographica. Supplement, 7(1): 37-133. 2(1)

Juárez-Valieri, R. D. \& Calvo, J. O. (2011) Revision of MUCPv 204, a Senonian Basal Titanosaur from Northern Patagonia. In: Paleontología y dinosarios desde América Latina, Calvo, González-Riga, Porfiri, Dos Santos (Eds.), pp. 143-152 
Kattah, S. D. S. (1991). Análise faciológica e estratigráfica do Jurássico Superior/Cretáceo Inferior na porção meridional da Bacia Sanfranciscana, oeste do estado de Minas Gerais. Ouro Preto. Dissertação de Mestrado, Universidade Federal de Ouro Preto.

Kattah, S. S., \& Koutsoukos, E. A. M. (1992). A ocorrência de radiolários em fácies sedimentares de origem marinha no Mesozóico da Bacia Sanfranciscana. Revista Escola de Minas, 45(1/2):214.

Kellner, A. W. A., Campos, D. D. A., \& Trotta, M. N. (2005). Description of a titanosaurid caudal series from the Bauru Group, Late Cretaceous of Brazil. Arquivos do Museu Nacional, 63(3), 529-564.

Kellner, A. W. A., Campos, D. A.,Azevedo, S. A. K., Trotta, M. N. F.,Henriques, D. D. R., Craik, M. M. T. \& Silva, H. P. (2006). On a new titanosaur sauropod from the Bauru Group, Late Cretaceous of Brazil. Boletim do Museu Nacional (Nova Série), Geologia, 74, 1-31.

Kellner, A. W., \& Azevedo, S. D. (1999). A new sauropod dinosaur (Titanosauria) from the Late Cretaceous of Brazil. National Science Museum Monographs, 15(111), e142.

Kellner, A. W., \& Campos, D. A. (2000). Brief review of dinosaur studies and perspectives in Brazil. Anais da Academia Brasileira de Ciências, 72(4), 509-538.

Kues, B. S., Lehman, T., \& Rigby, J. K. (1980). The teeth of Alamosaurus sanjuanensis, a Late Cretaceous sauropod. Journal of Paleontology, 864-869.

Kurzanov, S. M. \& Bannikov, A. F. (1983). A new sauropod from the Upper Cretaceous of Mongolia. Paleontological Journal, 2, 90-96.

Lacovara, K. J., Lamanna, M. C., Ibiricu, L. M., Poole, J. C., Schroeter, E. R., Ullmann, P. V., Voegele, K. K., Boles, Z. M., Carter, A. M., Fowler, E. K., Egerton, V. M., Moyer, A. E., Coughenour, C. L., Schein, J. P., Harris, J. D., Martínez, R. D. \& Novas, F. E. (2014). A gigantic, exceptionally complete titanosaurian sauropod dinosaur from southern Patagonia, Argentina. Scientific Reports, 4, 6196.

Le Loeuff, J. (1993). European titanosaurids. Revue de Paléobiologie, 7(volume spécial), 105-117. 
Le Loeuff, J., Suteethorn, S., \& Buffetaut, E. (2013). A new sauropod dinosaur from the Albian of Le Havre (Normandy, France). Oryctos, 10, 23-30.

Lehman, T. M., \& Coulson, A. B. (2002). A juvenile specimen of the sauropod dinosaur Alamosaurus sanjuanensis from the Upper Cretaceous of Big Bend National Park, Texas. Journal of Paleontology, 76(1), 156-172.

Leonardi, G., Duszczak, S. C. (1977). Ocorrência De Titanosaurinae (Sauropoda, Atlantosauridae) Na Formação Bauru (Cretaceo Superior) Em Guararapes, São Paulo. Em: Simpósio Regional De Geologia, 1., 1977, São Paulo. Atas... São Paulo: Sociedade Brasileira De Geologia/Núcleo Sp, P.396-403.

Li, L. G., Li, D. Q., You, H. L., \& Dodson, P. (2014). A New Titanosaurian Sauropod from the Hekou Group (Lower Cretaceous) of the Lanzhou-Minhe Basin, Gansu Province, China. PLoS One, 9(1), e85979.

Lima, M.R. (1979). Palinologia dos calcários laminados da Formação Areado, Cretáceo de Minas Gerais. In: $\mathbf{2}^{\mathbf{0}}$ Simpósio Regional de Geologia, Atas, Rio Claro, p. 203-216.

Lü, J., Pu, H., Xu, L., Jia, S., Zhang, J. \& Shen, C. (2014). Osteology of the giant sauropod dinosaur Ruyangosaurus giganteus Lü et al., 2009. Beijing: Geological Publishing House.

Lü., J., Xu, L., Jiang, X., Jia, S., Li, M., Yuan, C., Zhang, X. and Ji, Q., 2009. A preliminary report on the new dinosaurian fauna from the Cretaceous of the Ruyang Basin, Henan Province of central China. Journal of the Palaeontological Society of Korea, 25: 43-56.

Lydekker, R. 1877. Notices of new and other Vertebrata from Indian Tertiary and Secondary rocks. Records of the Geological Survey of India, 10: 30-43.

Machado, E. B., Avilla, L. S., Nava, W. R., Campos, D. A., \& Kellner, A. W. A. (2013). A new titanosaur sauropod from the Late Cretaceous of Brazil. Zootaxa, 3701(3), 301-321.

Maciel A. C. (1962). Nova Ocorrência De Vertebrados Fósseis Em Adamantina - Sp. Ciência E Cultura, 14 (3): P.167-168. 
Maddison, W. P., \& Maddison, W. P. (2016). Mesquite: a modular system for evolutionary analysis. Retrieved from http://mesquiteproject.org

Mannion P. D., Upchurch P, Barnes RN, Mateus O. (2013) Osteology of the Late Jurassic Portuguese sauropod dinosaur Lusotitan atalaiensis (Macronaria) and the evolutionary history of basal titanosauriforms. Zool. J. Linn. Soc. 168, 98- 206. (doi:10.1111/zoj.12029)

Mannion, P. D. (2009). A rebbachisaurid sauropod from the Lower Cretaceous of the Isle of Wight, England. Cretaceous Research, 30(3), 521-526.

Mannion, P. D., \& Calvo, J. O. (2011). Anatomy of the basal titanosaur (Dinosauria, Sauropoda) Andesaurus delgadoi from the mid-Cretaceous (Albian-early Cenomanian) Río Limay Formation, Neuquén Province, Argentina: implications for titanosaur systematics. Zoological Journal of the Linnean Society, 163(1), 155-181.

Mannion, P. D., \& Otero, A. (2012). A reappraisal of the Late Cretaceous Argentinean sauropod dinosaur Argyrosaurus superbus, with a description of a new titanosaur genus. Journal of Vertebrate Paleontology, 32(3), 614-638.

Mannion, P. D., Upchurch, P., Carrano, M. T., \& Barrett, P. M. (2011). Testing the effect of the rock record on diversity: a multidisciplinary approach to elucidating the generic richness of sauropodomorph dinosaurs through time. Biological Reviews, 86(1), 157-181.

Mannion, P. D., Upchurch, P., Schwarz, D., \& Wings, O. (2019). Taxonomic affinities of the putative titanosaurs from the Late Jurassic Tendaguru Formation of Tanzania: phylogenetic and biogeographic implications for eusauropod dinosaur evolution. Zoological Journal of the Linnean Society, 185(3), 784-909.

Mantell GA. (1853) On the Pelorosaurus: an undescribed gigantic terrestrial reptile, whose remains are associated with those of the Iguanodon and other saurians in the strata of Tilgate Forest, in Sussex. Phil Trans Roy Soc London. 140: 379-390.

Martin, V. (1994). Juveniles of the sauropod dinosaur Phuwiangosaurus from the Jurassic of Thailand. GAIA, 10, 147-153. 
Martin, V. (1999). Description of the type and referred material of Phuwiangosaurus sirindhornae Martin, Buffetaut and Suteethorn, 1994, a sauropod from the Lower Cretaceous of Thailand. Oryctos, 2, 39-91.

Martínez, R. D., Giménez, O., Rodríguez, J., Luna, M., \& Lamanna, M. C. (2004). An articulated specimen of the basal titanosaurian (Dinosauria: Sauropoda) Epachthosaurus sciuttoi from the early Late Cretaceous Bajo Barreal Formation of Chubut province, Argentina. Journal of vertebrate Paleontology, 24(1), 107-120.

Martínez, R. D., Lamanna, M. C., Novas, F. E., Ridgely, R. C., Casal, G. A., Martínez, J. E., Vita, J. R. \& Witmer, L. M. (2016). A basal lithostrotian titanosaur (Dinosauria: Sauropoda) with a complete skull: implications for the evolution and paleobiology of Titanosauria. PLoS One, 11(4), e0151661.

Martins-Neto, M.A., Pedrosa-Soares, A.C., Lima, S.A.A. (2001). Tectono-sedimentary evolution of sedimentary basins from Late Paleoproterozoic to Late Neoproterozoic in the São Francisco craton and Araçua fold belt, eastern Brazil. Sedimentary Geology 141-142, $343-370$.

Mateus, O., Jacobs, L. L., Schulp, A. S., Polcyn, M. J., Tavares, T. S., Buta Neto, A., ... \& Antunes, M. T. (2011). Angolatitan adamastor, a new sauropod dinosaur and the first record from Angola. Anais da Academia Brasileira de Ciências, 83(1), 221-233.

Matheron P. (1869). — Notice sur les Reptiles fossiles des dépôts fluvio-lacustres crétacés du bassin à lignite de Fuveau. Mémoire de l'Académie impériale des Sciences, BellesLettres et Arts de Marseille, 39 p.

McIntosh, J. S. (1990). Sauropoda. In: Weishampel, D. B., Dodson, P. \& Osmólska, H. (Eds.), The Dinosauria, 1, University of California Press, pp.345-401.

McIntosh, J. S., Miller, W. E., Stadtman, K. L. \& Gillette D. D. (1996) The osteology of Camarasaurus lewisi(Jensen, 1988). Brigham Young University, Geology Studies, 41, pp. 73-115.

McPhee, B. W., Mannion, P. D., Klerk, W. J. \& Choiniere, J. N. (2016). High diversity in the sauropod dinosaur fauna of the Lower Cretaceous Kirkwood Formation of South 
Africa: implications for the Jurassic-Cretaceous transition. Cretaceous Research, 59, 228248.

Mescolotti, P. C. (2017). Sistemas eólicos da Formação Três Barras, Cretáceo da Bacia Sanfranciscana. Dissertação de mestrado, Geociências e Meio Ambiente - IGCE.

Mezzalira, S. (1948). Distribuição dos fósseis do estado de São Paulo. Mineração e Metalurgia, 13 (76): p.249-255.

Mezzalira, S. (1959). Nota preliminar sobre as recentes descobertas paleontológicas no Estado de São Paulo, no período 1958-1959. Notas prévias, São Paulo, Instituto Geográfico e Geológico, 2: p.1-7.

Mezzalira, S. (1966). Os Fósseis do Estado de São Paulo. Boletim da Comissão Geográfica e Geológica de São Paulo, 45: p.1-132.

Navarrete, C., Casal, G., \& Martínez, R. (2011). Drusilasaura deseadensis gen. et sp. nov., un nuevo titanosaurio (Dinosauria-Sauropoda), de la Formación Bajo Barreal, Cretácico Superior del norte de Santa Cruz, Argentina. Revista Brasileira de Paleontologia, 14(1), $1-14$.

Nopcsa, B. F. (1930). Zur Systematik Und Biologie Der Sauropoden. Palæobiologica, 3, 40.

Novas, F., Salgado, L., Calvo, J., \& Agnolin, F. (2005). Giant titanosaur (Dinosauria, Sauropoda) from the Late Cretaceous of Patagonia. Revista del Museo Argentino de Ciencias Naturales Nueva Serie, 7(1), 31-36.

Nowinski, A. (1971). Nemegtosaurus mongoliensis n. gen., n. sp. (Sauropoda) from the uppermost Cretaceous of Mongolia. Palaeontologia Polonica, 25, 57-81.

Olshevsky, G. (1978). The Archosaurian Taxa. G \& T Enterprises, Toronto, 50p.

Otero, A. (2010). The appendicular skeleton of Neuquensaurus, a Late Cretaceous saltasaurine sauropod from Patagonia, Argentina. Acta Palaeontologica Polonica, 55(3), 399-427. 
Pacheco, J. A. (1913). Notas sobre a geologia do vale do Rio Grande a partir da foz do Rio Pardo até sua confluência com o Rio Paranaiba. Boletim da Comissão Geográfica e Geológica do Estado de São Paulo, 1: p.33-38.

Pereira, P., Marinho, T. S., Candeiro, C. R. A., \& Bergqvist, L. P. (2018). A new titanosaur osteoderm record from Brazil and its significance. Ameghiniana, 55 (6), 644-650.

Pires Domingues, R. A. (2009). Paleogeografia do Alto de Paracatu: O registro geológico dos bone-beds de dinossauros da bacia Sanfranciscana. (MSc. Dissertation), Universidade de São Paulo. 111p.

Poropat, S. F., Mannion, P. D., Upchurch, P., Hocknull, S. A., Kear, B. P., Kundrát, M., Tischler, T. R., Sloan, T., Sinapius, G. H. K., Elliott, J. A. \& Elliott, D. A. (2016). New Australian sauropods shed light on Cretaceous dinosaur palaeobiogeography. Scientific reports, 6,34467 .

Poropat, S. F., Mannion, P. D., Upchurch, P., Hocknull, S. A., Kear, B. P., \& Elliott, D. A. (2014). Reassessment of the non-titanosaurian somphospondylan Wintonotitan wattsi (Dinosauria: Sauropoda: Titanosauriformes) from the mid-Cretaceous Winton Formation, Queensland, Australia. Papers in Palaeontology, 1(1), 59-106.

Poropat, S. F., Nair, J. P., Syme, C. E., Mannion, P. D., Upchurch, P., Hocknull, S. A., ... \& Holland, T. (2017). Reappraisal of Austrosaurus mckillopi Longman, 1933 from the Allaru Mudstone of Queensland, Australia's first named Cretaceous sauropod dinosaur. Alcheringa: An Australasian Journal of Palaeontology, 41(4), 543-580.

Poropat, S. F., Upchurch, P., Mannion, P. D., Hocknull, S. A., Kear, B. P., Sloan, T., Sinapius, G. H. K. \& Elliott, D. A. (2015). Revision of the sauropod dinosaur Diamantinasaurus matildae Hocknull et al. 2009 from the mid-Cretaceous of Australia: implications for Gondwanan titanosauriform dispersal. Gondwana Research, 27(3), 9951033.

Powell, J. (1990). Epachthosaurus sciuttoi (gen. et sp. nov.) a sauropod dinosaur from the Cretaceous of Patagonia (Chubut Province). Actas Congr Argentino Paleontol Bioestrat, 5, 125-128. 
Powell, J. E. (1992). Osteología de Saltasaurus loricatus (Sauropoda-Titanosauridae) del Cretácico Superior argentino. In: Los dinosaurios y su entorno biótico II. Curso de Paleontología, 10 a 12 de julio de 1990: Actas (pp. 165-230). Instituto Juan de Valdés.

Powell, J. E. (2003). Revision of the South American titanosaurid dinosaurs: palaeobiological, palaeobiogeographical, and phylogenetic aspects. Records of the Queen Victoria Museum, 111: 1-173.

Price, L. I. (1947). Sedimentos mesozoicos na baía de São Marcos, estado do Maranhão. Notas prelim. Est. Div.Geol. Mineral., 53: p.1-7.

Price, L. I. (1961). Sobre os dinossáurios do Brasil. Anais da Academia Brasileira de Ciências, 33 (3-4): 28-29.

Remes, K., Ortega, F., Fierro, I., Joger, U., Kosma, R., Ferrer, J. M. M., ... \& Maga, A. (2009). A new basal sauropod dinosaur from the Middle Jurassic of Niger and the early evolution of Sauropoda. PLoS One, 4(9), e6924.

Rohn, R., \& Cavalheiro, M. C. T. (1996). Conchostráceos cretácicos da Bacia de Tucano (Bahia) e avaliação do potencial cronoestratigráfico destes crustáceos no Mesozóico do Brasil. Simpósio sobre o Cretáceo do Brasil, 4(1996), 157-167.

Royo-Torres, R., Alcalá, L., \& Cobos, A. (2012). A new specimen of the Cretaceous sauropod Tastavinsaurus sanzi from El Castellar (Teruel, Spain), and a phylogenetic analysis of the Laurasiformes. Cretaceous Research, 34, 61-83.

Royo-Torres, R., Upchurch, P., Kirkland, J. I., DeBlieux, D. D., Foster, J. R., Cobos, A., \& Alcalá, L. (2017). Descendants of the Jurassic turiasaurs from Iberia found refuge in the Early Cretaceous of western USA. Scientific reports, 7(1), 14311.

Salgado, L. (1996). Pellegrinisaurus powelli nov. Gen. et sp.(Sauropoda, Titanosauridae) from the Upper Cretaceous of lago Pellegrini, northwestem Patagonia, Argentina. Ameghiniana, 33(4), 355-365.

Salgado, L. (2003). Should we abandon the name Titanosauridae? Some comments on the taxonomy of titanosaurian sauropods (Dinosauria). Revista Española de Paleontología, 18(1), 15-21. 
Salgado, L., \& Azpilicueta, C. (2000). Un nuevo saltasaurino (Sauropoda, Titanosauridae) de la provincia de Río Negro (Formación Allen, Cretácico Superior), Patagonia, Argentina. Ameghiniana, 37(3), 259-264.

Salgado, L., \& Bonaparte, J. F. (2007). Sauropodomorpha. Patagonian mesozoic reptiles, $188-228$.

Salgado, L., \& Coria, R. A. (2009). Barrosasaurus casamiquelai gen. et sp. nov., a new titanosaur (Dinosauria, Sauropoda) from the Anacleto Formation (Late Cretaceous: early Campanian) of Sierra Barrosa (Neuquén, Argentina). Zootaxa, 2222(1), 1-16.

Salgado, L., \& De Souza Carvalho, I. (2008). Uberabatitan ribeiroi, a new titanosaur from the Marília formation (Bauru group, Upper Cretaceous), Minas Gerais, Brazil. Palaeontology, 51(4), 881-901.

Salgado, L., Apesteguía, S., \& Heredia, S. E. (2005). A new specimen of Neuquensaurus australis, a Late Cretaceous saltasaurine titanosaur from north Patagonia. Journal of vertebrate Paleontology, 25(3), 623-634.

Salgado, L., Coria, R. A., \& Calvo, J. O. (1997). Evolution of titanosaurid sauropods. I: Phylogenetic analysis based on the postcranial evidence. Ameghiniana, 34(1), 3-32.

Salgado, L., Gallina, P. A., \& Paulina Carabajal, A. (2014). Redescription of Bonatitan reigi (Sauropoda: Titanosauria), from the Campanian-Maastrichtian of the Río Negro Province (Argentina). Historical Biology, 27(5), 525-548.

Sallam, H. M., Gorscak, E., O’Connor, P. M., El-Dawoudi, I. A., El-Sayed, S., Saber, S., Kora, M. A., Sertich, J. J. W., Seiffert, E. R. \& Lamanna, M. C. (2018). New Egyptian sauropod reveals Late Cretaceous dinosaur dispersal between Europe and Africa. Nature Ecology \& Evolution, 2(3), 445.

Santos, M.E.C.M. (1971). Um nôvo artrópodo da Formação Areado, Estado de Minas Gerais. Anais da Academia Brasileira de Ciências 43, 415-420.

Santos, R.S. (1985). Laeliichthys ancestralis, novo gênero e espécies de Osteoglossiformes do Aptiano da Formação Areado, estado de Minas Gerais, Brasil, In: Paleontologia e Estratigrafia, Coletânea de Trabalhos Paleontológicos, Campos, D.A., Ferreira, C.S., Brito, I.M., Viana, C.F. (Eds.). DNPM, Brasília, pp. 161-167 
Santucci, R. M. (1999). Titanossauros Neocretácicos Do Grupo Bauru: Avaliação De Ocorrências E De Seu Potencial Paleobiogeográfico E Biocronológico. 1999. 57f. Monografia - Instituto de Geociências, Universidade de São Paulo, São Paulo.

Santucci, R. M. (2002). Revisão dos Titanosauridae (Saurischia, Sauropoda) do Cretáceo Superior Continental da Bacia Bauru. Dissertação de mestrado, Universidade Estadual Paulista, $170 \mathrm{p}$.

Santucci, R. M. Evolução e distribuição paleogeográfica dos Titanosauria (Saurischia, Sauropoda). (2005). Doctoral thesis. Instituto de Geociências e Ciências Exatas da Universidade Estadual Paulista.

Santucci, R. M., \& Arruda Campos, A. C. (2011). A new sauropod (Macronaria, Titanosauria) from the Adamantina Formation, Bauru Group, Upper Cretaceous of Brazil and the phylogenetic relationships of Aeolosaurini. Zootaxa, 33(3085), 1-33.

Santucci, R. M., \& Bertini, R. J. (2006a). A new titanosaur from western São Paulo State, Upper Cretaceous Bauru Group, south-east Brazil. Palaeontology, 49(1), 59-66.

Santucci, R. M., \& Bertini, R. J. (2006b). A large sauropod titanosaur from Peirópolis, Bauru Group, Brazil. Neues Jahrbuch fur Geologie und Palaontologie-Monatshefte, (6), 344-360.

Santucci, R. M., Bertini, R. J. (2001). Distribuição paleogeográfica e biocronológica dos titanossauros (Saurischia, Sauropoda) do Grupo Bauru, Cretáceo Superior do sudeste brasileiro. Revista Brasileira de Geociências, 31 (3): p.307-314.

Santucci, R.M., Pinto, R.L., Almeida, M.F., Souza, L.M., Mineiro, A.S., Santos, D.M. (2014). Um dente de terópode da Formação Quiricó, Bacia Sanfranciscana (Aptiano) do norte de Minas Gerais. In: IX Simpósio Brasileiro de Paleontologia de Vertebrados, Vitória, p. 124.

Sanz, J. L., Powell, J. E., Loeuff, J. Le, Martinez, R., \& Pereda-Suberbiola, X. (1999). Sauropod remains from the Upper Cretaceous of Laño (north central Spain). Titanosaur phylogenetic relationships. Estudios Del Museo de Ciencias Naturales de Alava, 14(1), $235-255$. 
Sassani, N., \& Bivens, G. T. (2017). The Chinese colossus: an evaluation of the phylogeny of Ruyangosaurus giganteus and its implications for titanosaur evolution (No. e2988v1). PeerJ Preprints.

Scorza, F.P., Santos, R.S. (1955). Ocorrência de folhelho fossilífero no município de Presidente Olegário, Minas Gerais. Boletim do Departamento Nacional de Produção Mineral - Divisão de Geologia e Mineralogia 155, 1-27.

Seeley, H. G. (1876). On Macrurosaurus semnus (Seeley), a long tailed animal with procoelous vertebrae from the Cambridge Upper Greensand, preserved in the Woodwardian Museum of the University of Cambridge. Quarterly Journal of the Geological Society, 32(1-4), 440-444.

Sereno, P. C. (1998). A rationale for phylogenetic definitions, with application to the higher-level taxonomy of Dinosauria [41-83]. Neues Jahrbuch für Geologie und Paläontologie-Abhandlungen, 41-83.

Sereno, P. C., McAllister, S., \& Brusatte, S. L. (2005). TaxonSearch: a relational database for suprageneric taxa and phylogenetic definitions. PhyloInformatics, 8(56), 1-25.

Steel, R. (1970). Saurischia. Fischer.

Tschopp, E., Tschopp, F. A., \& Mateus, O. (2018). Overlap Indices: Tools to quantify the amount of anatomical overlap among groups of incomplete terminal taxa in phylogenetic analyses. Acta Zoologica, 99(2), 169-176.

Tykoski, R. S. \& Fiorillo, A. R. (2017). An articulated cervical series of Alamosaurus sanjuanensis Gilmore, 1922 (Dinosauria, Sauropoda) from Texas: new perspective on the relationships of North America's last giant sauropod. Journal of Systematic Palaeontology, 15(5), 339-364.

Ullmann, P. V., \& Lacovara, K. J. (2016). Appendicular osteology of Dreadnoughtus schrani, a giant titanosaurian (Sauropoda, Titanosauria) from the Upper Cretaceous of Patagonia, Argentina. Journal of Vertebrate Paleontology, 36(6), e1225303.

Upchurch P. (1998). The phylogenetic relationships of sauropod dinosaurs. Zoological Journal of the Linnean Society 124, 43-103. 
Upchurch, P. (1995). The evolutionary history of sauropod dinosaurs. Philosophical Transactions of the Royal Society of London. Series B: Biological Sciences, 349(1330), 365-390.

Upchurch, P., Barrett, P. M., \& Dodson, P. (2004). Sauropoda In: Weishampel, D. B., Dodson, P. \& Osmólska, H. (Eds.), The Dinosauria, second edition, University of California Press, pp. 259-322.

Upchurch, P., Barrett, P. M., Xijin, Z., \& Xing, X. U. (2007). A re-evaluation of Chinshakiangosaurus chunghoensis Ye vide Dong 1992 (Dinosauria, Sauropodomorpha): implications for cranial evolution in basal sauropod dinosaurs. Geological Magazine, 144(2), 247-262.

Upchurch, P., Mannion, P. D., \& Barrett, P. M. (2011). Sauropod dinosaurs. In: Field Guide to English Wealden Fossils, Palaeontological Association, 476-525.

Upchurch, P., Mannion, P. D., \& Taylor, M. P. (2015). The anatomy and phylogenetic relationships of "Pelorosaurus "becklesii (Neosauropoda, Macronaria) from the Early Cretaceous of England. PloS one, 10(6), e0125819.

Vieira, P.L.C.R., Horta, R.M., Bittencourt, J. (2015). Geologia da região de Lagoa dos Patos, norte de Minas Gerais, e seu potencial paleontológico. In: Geosudeste 2015, Anais, Campos do Jordão, p. 142.

Whitlock, J. A. (2011). A phylogenetic analysis of Diplodocoidea (Saurischia: Sauropoda). Zoological Journal of the Linnean Society, 161(4), 872-915.

Whitlock, J. A., \& Wilson, J. A. (2013). Character distribution maps: a visualization method for comparative cladistics. Acta Zoologica, 94(4), 490-499.

Wild, R. (1991). Die Ostafrika-Reise von Eberhard Fraas und die Erforschung der Dinosaurier-Fundstelle Tendaguru. Stuttgarter Beitråge zur Naturkunde, Serie C, 30, 71-76.

Wilson J.A. (2002). Sauropod dinosaur phylogeny: critique and cladistic analysis. Zoological Journal of the Linnean Society 136, 215-275. 
Wilson, J. A. (2005). Redescription of the Mongolian sauropod Nemegtosaurus mongoliensis Nowinski (Dinosauria: Saurischia) and comments on Late Cretaceous sauropod diversity. Journal of Systematic Palaeontology, 3(3), 283-318.

Wilson, J. A. (2006a). An overview of titanosaur evolution and phylogeny. Actas de las III Jornadas sobre Dinosaurios y su Entorno. Burgos: Salas de los Infantes, 169, e190.

Wilson, J. A. (2006b). Anatomical nomenclature of fossil vertebrates: standardized terms or 'lingua franca'?. Journal of Vertebrate Paleontology, 26(3), 511-518.

Wilson, J. A., \& Carrano, M. T. (1999). Titanosaurs and the origin of "wide-gauge" trackways: a biomechanical and systematic perspective on sauropod locomotion. Paleobiology, 25(2), 252-267.

Wilson, J. A., \& Sereno, P. C. (1998). Early evolution and higher-level phylogeny of sauropod dinosaurs. Journal of Vertebrate Paleontology, 18(S2), 1-79.

Wilson, J. A., \& Upchurch, P. (2003). A revision of Titanosaurus Lydekker (dinosauriasauropoda), the first dinosaur genus with a 'Gondwanan'distribution. Journal of Systematic Palaeontology, 1(3), 125-160.

Wilson, J. A., Barrett, P. M., \& Carrano, M. T. (2011b). An associated partial skeleton of Jainosaurus cf. septentrionalis (Dinosauria: Sauropoda) from the Late Cretaceous of Chhota Simla, central India. Palaeontology, 54(5), 981-998.

Wilson, J. A., Michael, D. D., Ikejiri, T., Moacdieh, E. M., \& Whitlock, J. A. (2011a). A nomenclature for vertebral fossae in sauropods and other saurischian dinosaurs. PLoS One, 6(2), e17114.

Wilson, J. A., Pol, D., Carvalho, A. B. \& Zaher, H. (2016). The skull of the titanosaur Tapuiasaurus macedoi (Dinosauria: Sauropoda), a basal titanosaur from the Lower Cretaceous of Brazil. Zoological Journal of the Linnean Society, 178(3), 611-662.

Wilson, J., D'Emic, M., Rogers, C. A. C., Mohabey, D. M., \& SEn, S. (2009). Reassessment of sauropod dinosaur Jainosaurus (="Antarctosaurus") septentrionalis from the Upper Cretaceous of India. Contributions from the Museum of Paleontology, University of Michigan, Vol. 32, n. 2, p. 17-40. 
Woodward, A. S. (1910). On a tooth of Triassic dinosaur from S. Paulo, Brazil. Report of the Association for the Advancement of Science, 79: p.483.

You, H., Feng, T., \& Zhexi, L. (2003). A new basal titanosaur (Dinosauria: Sauropoda) from the Early Cretaceous of China. Acta Geologica Sinica-English Edition, 77(4), 424429.

Zaher, H., Pol, D., Carvalho, A. B., Nascimento, P. M., Riccomini, C., Larson, P., A., Juaréz-Vallieri, R., Pires-Domingues, R., Da Silva Jr., N. J. \& Campos, D. A. (2011). A complete skull of an Early Cretaceous sauropod and the evolution of advanced titanosaurians. PLoS One, 6(2), e16663.

Zhang, Y. (1988) The Middle Jurassic dinosaur fauna from Dashanpu, Zigong, Sichuan, vol. III. sauropod dinosaurs (I): Shunosaurus. Sichuan Publishing House of Science and Technology.

Zurriaguz, V., \& Powell, J. (2015). New contributions to the presacral osteology of Saltasaurus loricatus (Sauropoda, Titanosauria) from the Upper Cretaceous of northern Argentina. Cretaceous Research, 54, 283-300. 